\title{
Membrane Proteins of the Nerve Growth Cone and Their Developmental Regulation
}

\author{
Philip Simkowitz, ${ }^{a}$ Leland Ellis, ${ }^{\mathrm{b}}$ and Karl H. Pfenninger \\ Department of Anatomy and Cell Biology, Columbia University, College of Physicians \& Surgeons, New York, New York \\ 10032, and Department of Cellular and Structural Biology, University of Colorado Health Sciences Center, Denver, \\ Colorado 80262
}

The membrane polypeptides of growth cone fragments ("growth cone particles," GCPs) isolated from fetal rat brain by subcellular fractionation have been analyzed in further detail. The major polypeptides of salt-washed GCP membranes detected by 1-dimensional gel electrophoresis (Ellis et al., 1985b) resolve in 2-dimensional gels as a spot of 52 $\mathrm{kDa}$ that comigrates with $\beta$-tubulin and reacts with anti- $\beta$ tubulin; a $46 \mathrm{kDa}, \mathrm{p} / 4.3$, polypeptide (pp46) that has no equivalent in the soluble fraction and is identical to one of the GCP's major phosphoproteins (Katz et al., 1985) and to GAP43 (Willard et al., 1985); a spot of $42 \mathrm{kDa}$ that comigrates with actin; and a species of $34 \mathrm{kDa}$ (p34) without soluble equivalent. The prominent $38 \mathrm{kDa}$ doublet identified in 1 dimensional gels is difficult to resolve in 2-dimensional gels. The major phosphoproteins pp80ac, pp46, and pp40 (Katz et al., 1985), as well as p34 partition into the oil phase of Triton $X-114$ extracts, suggesting that they are integral membrane proteins, at least in our experimental conditions. The properties of pp46 reported here are in conflict with the highly hydrophilic amino acid sequence predicted for GAP43/ B50/F1 (Basi et al., 1987; Karns et al., 1987).

Growth-cone and presynaptic membrane proteins are compared as follows. After eye injection of ${ }^{35}$ S-methionine, GCPs and synaptosomes are isolated from the target areas of optic nerve of fetal and adult rats, respectively. Polypeptides are separated by 1- and 2-dimensional gel electrophoresis and the radiolabeled species identified fluorographically. The comparison of labeled GCP and

\footnotetext{
Received Apr. 6, 1988; revised Aug. 17, 1988; accepted Aug. 22, 1988.

We are particularly indebted to Dr. G. Piperno of Rockefeller University for providing the anti- $\beta$-tubulin antiserum and to Drs. G. May and J. Rosenbaum of Yale University for running GCP and subfraction samples in their electrophoresis system. Drs. Piperno, Rosenbaum, and May also offered excellent advice regarding the identification of the $52 \mathrm{kDa}$ polypeptide. We also wish to express our gratitude to Drs. Flora Katz (University of Texas), Richard Ambron (Columbia I Iniversity), Marie-France Maylie-Pfenninger (University of Colorado), Beth Schachter (Mt. Sinai Medical Center, New York), and Minx Fuller (University of Colorado) for many helpful discussions and valuable suggestions during the course of this study.

Furthermore, we wish to thank Edith Abreu, Linda B. Friedman, Greta Katzauer, and especially Robert Wheeler for expert technical assistance and Ruth Carpino and Carmel McGuire for excellent secretarial help. This work was supported by NSF Grants BNS 79-14070 and BNS 85-10298 (to K.H.P.), an NRSA from NINCDS (to L.E.), and a grant from the National Spinal Cord Injury Association.

Correspondence should be addressed to Karl H. Pfenninger, M.D., Department of Cellular and Structural Biology, University of Colorado School of Medicine, 4200 East Ninth Avenue, Denver, CO 80262.

" Present address: Department of Psychiatry, New York University Medica Center, New York, NY 10016.

' Present address: Howard Hughes Medical Institute, University of Texas Health Services Center at Dallas, 5323 Harry Hincs Blvd., Room Y4-226, Dallas, TX 75235-9050.
}

Copyright (C) 1989 Society for Neuroscience $0270-6474 / 89 / 031004-14 \$ 02.00 / 0$ synaptosome polypeptides shows that all 5 major Coomassie blue-stained polypeptides of GCP membranes (52, $46,42,38,34 \mathrm{kDa}$ ) are intensely labeled after eye injection. However, in synaptosomes, these polypeptides are weakly labeled if at all; instead, an intensely labeled polypeptide of $28 \mathrm{kDa}$, and several additional species not seen in GCPs, have appeared. Therefore, the major growth cone membrane proteins are developmentally regulated, and the rates of synthesis and transport into the axonal ending of neuronal polypeptides change dramatically at the time of synaptogenesis.

Recent advances with the subcellular fractionation of fetal brain have lead to the development of methods for the isolation of "growth cone particles," or GCPs (Pfenninger et al., 1983; see also Gordon-Weeks and Lockerbie, 1984). Morphological criteria and the results of mixing experiments suggest that GCPs are indeed derived from nerve growth cones. The neuronal (or nerve-terminal) origin of GCPs is further supported by the finding that phosphoproteins in GCPs are qualitatively similar to those in synaptosomes (Ellis et al., 1985a) and include the growthassociated protein GAP43 (Meiri et al., 1986). More recently, we have described the preparation of a membrane subfraction (GCM) derived from GCPs (Ellis et al., 1985b). GCMs contain a simplified pattern of major polypeptides and are enriched in a $185-255 \mathrm{kDa}$ glycoprotein, which is neuron specific and associated with neurite growth (Ellis et al., 1985b; Wallis et al., 1985). Our present objective is to describe the major GCM polypeptides in further detail and to investigate their developmental fate.

Among the approaches used to achieve the goals outlined above is an experimental paradigm involving axoplasmic transport. Radiolabeling a specific group of neurons (those in the retina) would be expected to lead to the appearance of radioactive proteins in the respective GCPs but not in non-neuronal cell fragments isolated from a remote target area. Such an axoplasmic transport scheme, used in the adult, is also the only way to label the presynaptic terminal selectively for comparison with the GCP. Comparison of labeled GCP and synaptosome proteins should provide information on the developmental regulation of the synthesis and/or axoplasmic transport of components present in the 2 structures. Axoplasmic transport has been exploited by numerous investigators to study the proximodistal transfer of neuronal proteins under different conditions (for review, see Schwartz, 1979; Grafstein and Forman, 1980) and has been particularly useful for identifying proteins specifically associated with axon growth and regeneration (e.g., Grafstein and Murray, 1969; Cancalon and Elam, 1980; Skene and Willard, 
1981a, b). However, in many cases the analyzed proteins have included those of the axon shafts contained in the target region, rather than focusing on those arriving at the distal tip. To this end, several laboratories have isolated synaptosomes but have stopped short of specifying proteins by molecular mass (Marko et al., 1971; Carton and Appel, 1973; Weiss et al., 1979; Garner and Mahler, 1982). The studies presented here combine an axoplasmic transport paradigm with GCP isolation and include experiments in relatively young fetus ( $16 \mathrm{~d}$ gestation), at a stage when the majority of axons from the retinal ganglion cells have not yet reached their target sites. A preliminary report of part of this work has been presented in abstract form (Simkowitz and Pfenninger, 1983).

\section{Materials and Methods}

\section{Materials}

Ultrapure sucrose was from Schwartz/Mann (Orangeburg, NY), N-Tris[hydroxymethyl]methyl-2-aminoethanesulfonic acid (TES) and Tris(hydroxymethyl)aminomethane (Tris, as Trizma base) were from Sigma Chemical Co. (St. Louis, MO). Protein standards for SDS-PAGE were from Pharmacia (Piscataway, NJ) and BioRad (Richmond, CA). SDS was from British Drug House (obtained through Gallard-Schlesinger Chemical Mfg. Co., Carle Place, NY). Ampholytes were from LKB Instruments (Paramus, NJ). All chemicals for SDS-PAGE were electrophoresis grade. All other chemicals were reagent grade. Nitrocellulose was from Schleicher and Schuell, Inc. (Keene, NH; BA85, $0.45 \mu \mathrm{m}$ ). Immunochemicals were from Boehringer Mannheim (Indianapolis, IN).

\section{Radiolabeling fetal optic nerve}

One litter of fetal Sprague-Dawley albino rats (CAMM Research, Mountainside, NJ) is required for ocular injection and additional litters, usually 3 or 4, to supply nonradioactive brain tissue as carrier (see below). The gestational ages of the litters are designated F15, F16, and F17 (for fetal days 15,16 , and 17), counting the day the vaginal plug is observed as day 0 . The protocol for injection of the fetal rat eyes is essentially identical for all 3 gestational ages. The mother is injected intraperitoneally with $2 \mu \mathrm{l} / \mathrm{gm}$ body weight of Chloropent (Fort Dodge Laboratories, Fort Dodge, IA). Prior to attainment of complete anesthesia, the mother is given, per os, $20 \mu \mathrm{l}$ of a $20 \mathrm{mg} / \mathrm{ml}$ oil-based solution of nifedipine, a $\mathrm{Ca}^{2+}$ blocker that relaxes the smooth muscle of the uterus. Additional nifedipine is applied to the surface of the exposed uterus as each fetus is accessed. In a position overlying one eye of the fetus, the uterine wall is opened with an incision about $3 \mathrm{~mm}$ long, and sutures are placed around it so as to prevent expulsion of the fetus. In F17 fetus the eyelids have to be slit open to expose the cornea. Using a micropipet and micromanipulator, the exposed eye is injected with ${ }^{35} \mathrm{~S}$-methionine (details below), and then the uterine wall is sutured closed. Approximately 10 fetuses are injected, each in one eye. Afterward the mother's abdomen is closed.

The solution for injection consists of $5 \mathrm{mCi} / \mu 1{ }^{35} \mathrm{~S}-(\mathrm{L})$-methionine (NEN, Inc., Boston; 3-5 mM) in distilled $\mathrm{H}_{2} \mathrm{O}$. Radioisotope is first dried in a Speed-Vac vacuum concentrator, resuspended in distilled $\mathrm{H}_{2} \mathrm{O}$, and then drawn up into a beveled micropipet (tip diameter, about $30 \mu \mathrm{m})$. The volume of injection, about $10 \mathrm{nl}$, containing $100 \mu \mathrm{Ci}$ isotope, is delivered by pressure.

Four hours after injection, the mother's abdomen is reopened and each injected fetus is, in turn, removed and its brain dissected free. The brain is subdivided into 3 regions: telencephalon, di- and mesencephalon, and met- and myelencephalon. Enough cold carrier brain tissue from $\mathrm{F} 17$ or F18 fetus is added to provide cach sample with a wct wcight of approximately $2 \mathrm{gm}$. The samples are then processed to produce GCPs. In control experiments, F16 and F17 fetus are injected intraabdominally with ${ }^{35} \mathrm{~S}$-methionine, and GCPs are prepared $4 \mathrm{hr}$ later from the 3 brain regions in order to assess the relative amounts of systemic labeling.

\section{Preparation of GCPs and their fractions}

The GCP fraction is isolated as described in detail in a previous paper (Pfenninger et al., 1983): A low-speed supernatant prepared from fetal rat brain (17 or $18 \mathrm{~d}$ gestation) is spun to equilibrium on a discontinuous sucrose density gradient. The " $\mathrm{A}$ "-fraction is collected from the 0.32 $\mathrm{M} / 0.75 \mathrm{M}$ interface. GCMs are prepared from the "A"-fraction as described (Ellis et al., 1985b). In brief, the "A"-fraction is diluted 3- to 4-fold with $0.32 \mathrm{M}$ sucrose, and GCPs are collected as a pellet (P1) by centrifugation at $39,800 \times g$ (centrifugal forces are $g_{\max }$ unless indicated otherwise) for $30 \mathrm{~min}$ at $4^{\circ} \mathrm{C}$. To lyse the GCPs, P1 is resuspended in $6 \mathrm{~mm}$ Tris- $\mathrm{HCl}, \mathrm{pH} 8.1$, containing $0.5 \mathrm{~mm}$ EDTA and stirred at $4^{\circ} \mathrm{C}$ for $45 \mathrm{~min}$. The material pelleted after $60 \mathrm{~min}$ at $200,000 \times \mathrm{g}$ is termed lysed GCPs. Soluble proteins are precipitated from the lysis supernatant by the addition of $50 \%$ ice-cold trichloroacetic acid (TCA) to a final concentration of $8.3 \%$ and collected by centrifugation $(11,200 \times g$ for $20 \mathrm{~min}$, at $4^{\circ} \mathrm{C}$ ). The resulting pellet is washed 3 times with ice-cold diethylether to remove TCA (Fujiki et al., 1982) and solubilized in sample buffer for electrophoresis (see below). For the preparation of GCP membranes (GCM), the lysed material is spun onto a $1 \mathrm{~m}$ sucrose cushion containing $0.5 \mathrm{~mm}$ EDTA at $200,000 \times \mathrm{g}$, for $60 \mathrm{~min}$ at $4^{\circ} \mathrm{C}$. The crude membrane fraction is collected at the Tris/sucrose interface and treated with $0.3 \mathrm{M} \mathrm{Na}_{2} \mathrm{SO}_{4}$ plus $20 \mu \mathrm{g} / \mathrm{ml}$ saponin' for $30 \mathrm{~min}$ at $4^{\circ} \mathrm{C}$, with stirring (Castle and Palade, 1978). The washed membranes are collected by centrifugation at $200,000 \times g$ for $60 \mathrm{~min}$ at $4^{\circ} \mathrm{C}$. The pellet (P3) is washed twice with water, resuspended in $50 \mu \mathrm{l}$ of water by homogenization in a glass-glass grinder (Bees-Knees; Pierce Chemical Co., Rockford, IL), and either prepared immediately for SDS-PAGE by adding an equal volume of twice-concentrated sample buffer (Laemmli, 1970) or stored frozen at $-20^{\circ} \mathrm{C}$ until used.

\section{Phosphorylation of GCPS}

Pelleted GCPs $(\mathrm{Pl} ; 50 \mu \mathrm{g}$ protein in $50 \mu \mathrm{l})$ arc incubatcd for $15 \mathrm{scc}$ at $30^{\circ} \mathrm{C}$ in $50 \mathrm{~mm}$ PIPES buffer, $\mathrm{pH} 7.0$, containing $5 \mu \mathrm{M}{ }^{32} \mathrm{P}$-ATP (25 $\mathrm{Ci} / \mathrm{mm}$; ICN Radiochemicals), $0.7 \mathrm{~mm} \mathrm{Ca}^{2+}, 0.4 \mathrm{~mm}$ EGTA, $10 \mathrm{~mm}$ $\mathrm{MgCl}_{2}$, and $10-20 \mu \mathrm{g} / \mathrm{ml}$ saponin for phosphorylation of substrates of calcium-dependent kinases (Katz et al., 1985). The reaction is stopped by the addition of $2 \times$ Laemmli electrophoresis buffer (Laemmli, 1970) or of the detergent Triton X-114 (see below). Phosphoproteins separated by 1- or 2-dimensional gel electrophoresis are detected radioautographically, with Kodak X-Omat film.

\section{Preparation of radiolabeled synaptic endings from optic nerve}

For each experiment, 5 adult Sprague-Dawley rats are anesthetized in the manner described above. A 30 gauge needle, connected by waterfilled polyethylene tubing to a $10 \mu \mathrm{l}$ syringe, is used to inject the radioisotope through the sclera into the vitreous. ${ }^{35} \mathrm{~S}$-methionine, $500 \mu \mathrm{Ci}$, is administered in a $1.0 \mu \mathrm{l}$ aliquot to each eye of the 5 rats for a total of $5 \mathrm{mCi}$. After 12 or $96 \mathrm{hr}$, the animals are killed, and the superior colliculi and lateral geniculate nuclei are removed. The tissue is fractionated to isolate synaptosomes essentially as described by Cohen et al. (1977). Tissues are homogenized in $0.32 \mathrm{~m}$ sucrose containing $1 \mathrm{~mm}$ $\mathrm{NaHCO}_{3}, 1 \mathrm{mM} \mathrm{MgCl}$, and $0.5 \mathrm{mM} \mathrm{CaCl}_{2}$ (solution A) at a ratio of $10 \%$ wet weight/volume, filtered through a $100 \mu \mathrm{m}$ nylon mesh screen, and centrifuged at $1400 \times g_{a v}$ for $10 \mathrm{~min}$. The resulting pellet is resuspended and respun at same speed for $10 \mathrm{~min}$. The 2 supernatants are combined and centrifuged at 13,800 $\times g_{\mathrm{av}}$ for 10 min (Beckman JA-17 rotor). The pellet is homogenized in $1.5 \mathrm{ml}$ of $0.32 \mathrm{M}$ sucrose plus 1 mM $\mathrm{NaHCO}_{3}$ (solution B), layered onto a 3-step sucrose density gradient $(2.6 \mathrm{M}, 7 \mathrm{ml} / 1.2 \mathrm{M}, 15 \mathrm{ml} / 1.0 \mathrm{M}, 15 \mathrm{ml})$ and spun at $131,700 \times g_{\mathrm{av}}$ for 40 min using a vertical rotor (Beckman VTi50). The band formed at the $1.0 / 1.2 \mathrm{M}$ sucrose interface is collected, diluted in 4 volumes of solution $\mathrm{A}$, and pelleted for $30 \mathrm{~min}$ at $27,200 \times g_{\text {av }}$. The pelleted synaptosome fraction is resuspended in PBS, lysed, and pelleted in the same manner as GCPs (see above). Control tissue, to assay for labeling by blood-borne radioactivity, is taken from frontal cortex and processed identically.

\section{Light microscopic radioautography}

Sections, $7 \mu \mathrm{m}$ thick, are made of paraffin-embedded heads of F15, F16, and $\mathrm{F} 17$ fetus that have been injected intraocularly with ${ }^{35}$ S-methionine as described above and fixed with $4 \%$ paraformaldehyde by immersion. The sections are cut in the coronal plane and collected serially. Sections arc staincd with toluidine bluc and coatcd with NTB-2 cmulsion (Eastman Kodak, Rochester, NY). The exposure time of radioautograms is $12 \mathrm{hr}-10 \mathrm{~d}$.

\footnotetext{
The saponin insures good access by the salt to all aspects of the membrane fragments through permeabilization.
} 


\section{Biochemical methods}

Protein concentrations are determined according to a modified method of Bradford (Bradford, 1976; BioRad reagent). $\mathrm{NaOH}$ is added to sample aliquots and standard tubes to a final concentration of $10 \mathrm{~mm}$. This solubilizes membrane samples and gives better reproducibility. Bovine plasma gamma globulin is used as standard.

Extraction with Triton $X-114$. Pelleted lysed GCPs or ${ }^{32}$ P-labeled GCPs are extracted with the detergent Triton X-114 (TX-114) in order to study the partitioning of (phospho)proteins into an aqueous or hydrophobic environment (Bordier, 1981; Pryde and Phillips, 1986). Samples are solubilized in cold $2 \%$ TX-114 in Tris-buffered saline, pH 7.4, insoluble material is spun out, and the supernatant is loaded onto a cushion of $6 \%$ sucrose and $0.06 \% \mathrm{TX}-114$ in the same buffer. After warming to $30^{\circ} \mathrm{C}$, the tubes are spun at $5000 \times g$ for 5 min to separate the "oil" phase from the aqueous phase. Oil and aqueous phases are mixed with sample buffer for 1- or 2-dimensional gel electrophoresis.

Analysis of proteins by gel electrophoresis. SDS-PAGE is performed according to the method of Laemmli (1970). Gels consist of a 5-15\% acrylamide gradient with the dimensions $140 \times 240 \times 0.75 \mathrm{~mm}$, and a $20 \mathrm{~mm}$ stacking gel of $3 \%$ acrylamide. Samples are run at a constant current of $15 \mathrm{~mA}$ for a distance of $200 \mathrm{~mm}$ in the resolving gel. They are stained with Coomassie blue (Weber and Osborn, 1969). Molecular masses are calibrated using as standard proteins: myosin $(210 \mathrm{kDa})$, $\beta$-galactosidase (1 16 kDa), phosphorylase b $(94 \mathrm{kDa})$, albumin $(67 \mathrm{kDa})$, ovalbumin $(43 \mathrm{kDa})$, carbonic anhydrase $(30 \mathrm{kDa})$, trypsin inhibitor (20 kDa), and $\alpha$-lactalbumin (14 kDa). Isoelectric focusing (IEF) is performed as described by O'Farrell (1975). Nonequilibrium pH-gradient gel electrophoresis (NEPHGE) is performed as described by O'Farrell and collaborators (1977), with the following modifications: (1) the sample buffer and gels for the first dimension contain $1.6 \%$ Ampholines of pH 3.5-10 and $0.4 \%$ Ampholines of pH 3.5-5; (2) samples consist of $30-125 \mu \mathrm{g}$ of protein in a final volume of $100 \mu \mathrm{l}$; (3) gels for the first dimension are poured to a height of $13 \mathrm{~cm}$ in glass tubes $(160 \times 2 \mathrm{~mm}$ i.d.). Electrophoresis is at constant voltage for $1600 \mathrm{~V} \mathrm{hr}$. Second-dimension gels are 5-15\% gradient gels as described above. Some 2-dimensional gels are stained with silver (Morrissey, 1981).

Electrophoretic transfer of proteins from polyacrylamide gels to nitrocellulose paper is performed in an electroblot apparatus (E-C Apparatus Corp., St. Petersburg, FL) at $300 \mathrm{~mA}$ for $1 \mathrm{hr}$ as described by Towbin and collaborators (1979). Blots are processed essentially as described by Hawkes and collaborators (1982). Antibodies are detected using a HRP-conjugated second antibody (immunoaffinity-purified goat anti-rabbit IgG, light- and heavy-chain-specific), followed by development with 4-chloro-1-naphthol (Aldrich Chemical Co., Milwaukee, WI). For visualization of protein bands or spots prior to antibody staining, blots are stained with silver (Yuen et al., 1983), followed by immunostaining as above. This method results in a blue peroxidase reaction product on a white protein spot or band, against the light-brown background of the nitrocellulose paper, and it allows the precise correlation of a protein band or spot with the antigen detected by immunostaining (protocol suggested by Dr. Minx Fuller, University of Colorado).

Fluorography of 1- and 2-dimensional gels is done by treating the gel (previously photographed) with either $1 \mathrm{M}$ sodium salicylate or Amplify (Amersham Corp., Arlington Heights, IL) for $30 \mathrm{~min}$. The dried gels are sandwiched with pretlashed XAR-2 Kodak film for exposure.

\section{Quantitation of incorporated radiolabel}

Sample aliquots are added to neopeptone $(0.2 \%)$ and precipitated with TCA to a final concentration of $10 \%$. Precipitate is pelleted at $500 \times g$ for $30 \mathrm{~min}$, washed once with $5 \% \mathrm{TCA}$, dissolved in $100 \mu \mathrm{l}$ of $1 \mathrm{~N}$ $\mathrm{NaOH}$, and then mixed with Liquiscint (National Diagnostics, Parsippany, NJ). For quantitative analysis of ${ }^{35} \mathrm{~S}$-labeled protein we compare diencephalon (D), the region containing the growing optic nerves and their eventual targets, with 2 brain regions devoid of optic tract (but labeled from the bloodstream; see Fig. 5), the telencephalon (T) and the myelencephalon (M). In all calculations the values for $M$ are used as the denominator for normalization.

Because of variations in protein recovery among fractionations (uneven addition of carrier, differences in collections, etc.), total incorporation (cpm) for each fraction is multiplied by a correction factor. These factors $(F)$ are determined for each fraction $(x)$, for $\mathrm{T}$ and $\mathrm{D}$, as ratios

$$
F_{\mathrm{T}(x)}=P_{\mathrm{M}(x)} / P_{\mathrm{T}(x)} \text { or } F_{\mathrm{D}(x)}=P_{\mathrm{M}(x)} / P_{\mathrm{D}(x) \%}
$$

where $P_{\mathrm{M}(x)}, P_{\mathrm{T}(x)}$, and $P_{\mathrm{D}(\mathrm{x})}$ are protein yields relative to homogenate of that fraction $(x)$. Because the incorporation of ${ }^{35} S$-methionine differs from experiment to experiment, the corrected counts for each fraction of $T$ and $D$ are divided by the corresponding value obtained for $M$. This results in dimensionless ratios for each fraction of each experiment. These values can be averaged across experiments and compared, and statistical analyses can be performed. An example of the numerical treatment of one experiment is given in the Appendix.

\section{Results}

\section{Polypeptides of GCMs}

GCPs are biochemically complex, containing approximately 70 polypeptide bands on 1-dimensional SDS-polyacrylamide gels when stained with silver, as reported by Ellis et al. (1985b). When lysed to release their cytoplasmic contents and then saltwashed to produce purified GCM, we see 2 distinctive patterns for lysis supernatant and GCM. Lysis supernatant contains almost the entire complement of GCP polypeptides and consists predominantly of 2 species of 52 and $42 \mathrm{kDa}$, respectively. In contrast to these soluble proteins, GCMs contain a simple polypeptide pattern, with major bands of 52,46 , and $42 \mathrm{kDa}$ and doublets at 38 and $34 \mathrm{kDa}$. The doublets at 38 and $34 \mathrm{kDa}$ are substantially enriched compared with the GCP pattern and are represented minimally, if at all, in the lysis supernatant.

A more thorough analysis is provided here by differential detergent extraction (see below) and by 2-dimensional gel electrophoresis. GCPs are seen to contain approximately 50 polypeptides revealed by Coomassie blue staining (Fig. 1, GCP). The electrophoretic behavior of 2 major GCP spots of 52 and $42 \mathrm{kDa}$ is identical to that of the 2 major polypeptides visible in homogenates of fetal brain (Fig. 1, F17H). In 1- and 2-dimensional gels, the major $52 \mathrm{kDa}$ protein comigrates with tubulin isolated from rat brain (data not shown). To determine whether the major $52 \mathrm{kDa}$ protein is immunochemically identical with brain tubulin, homogenate and GCP proteins, separated by 2D-NEPHGE, are electrophoretically transferred onto nitrocellulose paper and stained with a rabbit antiserum specific for $\beta$-tubulin (Piperno and Luck, 1977). As seen in Figure 2, the lower portion of the major $52 \mathrm{kDa}$ spot on 2D-NEPHGE gels of both homogenate $(\mathrm{F} 17 \mathrm{H})$ and GCP binds specifically the anti- $\beta$-tubulin antibody. The electrophoretic behaviors of these immunochemically identified $\beta$-tubulin species are identical in the conditions used. Thus, $\beta$-tubulin is a major polypeptide of the GCP. Based on its electrophoretic mobility, the $42 \mathrm{kDa}$ spot is likely to be actin, as it comigrates in 2 dimensions with actin isolated from rat heart (data not shown).

In accordance with the results obtained by 1 -dimensional gel electrophoresis, 2D-NEPHGE shows that hypotonic lysis of the GCP releases most of the polypeptide species detected in the whole particle (Fig. 1, LYS). This includes the bulk of the 52 and $42 \mathrm{kDa}$ bands. Yet, the salt-washed, saponin-permeabilized GCMs also contain significant amounts of these 2 proteins (Fig. 1, GCM). In addition, GCMs contain distinct polypeptides that are substantially enriched with respect to the GCP and that are not visible in the lysis supernatant. A major polypeptide at 34 $\mathrm{kDa}(\mathrm{p} 34)$ is highly enriched in the GCMs compared with the GCP (see arrowhead) or the soluble proteins. While 1-dimensional gels show that both lysis supernatant and GCM contain a major polypeptide band at $46 \mathrm{kDa}$, analysis by $2 \mathrm{D}-\mathrm{NEPHGE}$ or IEF demonstrates that, in fact, the $46 \mathrm{kDa}$ region contains several polypeptides. A complex of 3 closely spaced, acidic spots of $46 \mathrm{kDa}$ is highly enriched in the GCM (Fig. 1). As already described (Ellis et al., 1985b), 1-dimensional SDS-PAGE shows a further polypeptide that is enriched in GCMs. This protein, 


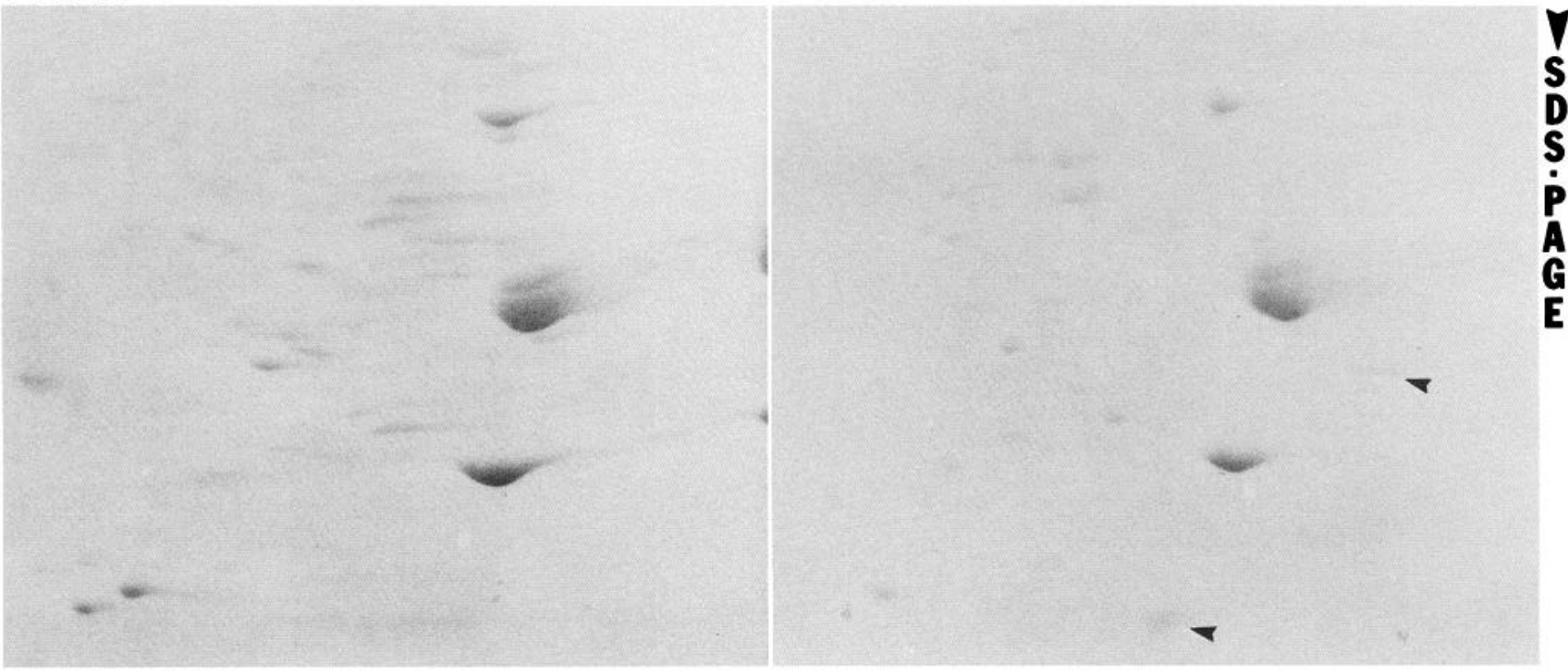

Figure 1. Two-dimensional NEPHGE analysis of proteins of whole fetal brain homogenate (17 d gestation; $F 17 H)$, pelleted growth cone particles $(G C P)$, GCP lysis supernatant $(L Y S)$, and salt-washed GCP membranes $(G C M)$. All gels were stained with Coomassie blue. The photographs show all stained spots of the gels. The areas shown include a pH range of 4-8 and a $\mathrm{M}_{\mathrm{r}}$ range of $20-150 \mathrm{kDa}$. The markers at the lower right denote molecular masses (from top to bottom) of $52,46,42$, and $34 \mathrm{kDa}$, respectively. Note the changes in the patterns from $\mathrm{H}$ to GCM. Of particular interest is the emergence of 2 major spots in GCM at 46 and $34 \mathrm{kDa}$, which are just barely visible in GCP (arrowheads) and have no counterpart in LYS.

p38, is difficult to identify in 2-dimensional gels (NEPHGE, IEF, or acidic IEF). It tends to be smeared over a broad $\mathrm{pH}$ range (Greenberger and Pfenninger, 1986) or not to be visible at all under the present experimental conditions.

\section{Phase separation of GCPS}

Triton X-114 has the unusual property of forming a 2-phase system at warm temperatures, and most membrane proteins that have significant hydrophobic regions are known to partition into its detergent-rich oil phase (Bordier, 1981; Pryde and Phillips, 1986). Figure 3 shows the partitioning of GCP proteins into the $2 \mathrm{TX}-114$ phases. The silver-stained 2-dimensional gel (Fig. $3 A$ ) prepared from the oil phase contains prominent proteins at $46 \mathrm{kDa}$ (triplet) and $34 \mathrm{kDa}$. All other species are minor. The $46 \mathrm{kDa}$ protein comigrates precisely with, and exhibits the same microheterogeneity as, the major phosphoprotein pp46 identified earlier in GCPs (Katz et al., 1985; Hyman and Pfenninger, 1987). The distribution between aqueous and oil phases of GCP protein phosphorylated in the presence of $\mathrm{Ca}^{2+}$ is shown in Figure $3 C$. Three major phosphorylated bands are seen in the oil phase at 40,46 and $80 \mathrm{kDa}$, respectively. In contrast, only one major band is seen in the aqueous phase, at about 53 


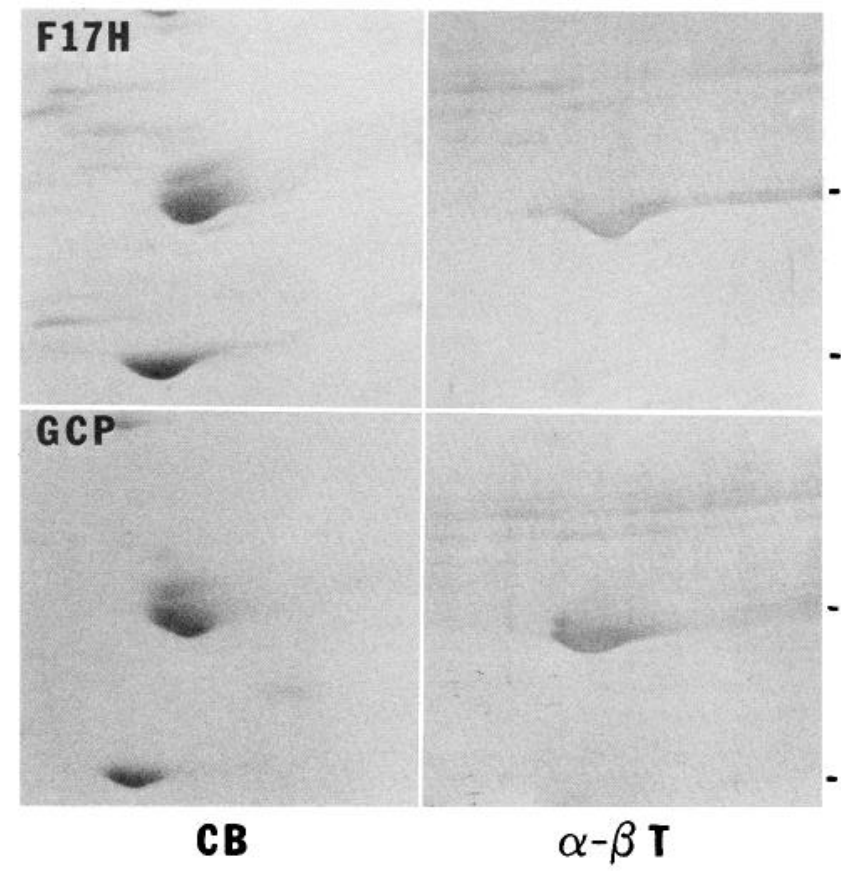

Figure 2. Detail of 2-dimensional NEPHGE patterns of GCP and fetal brain homogenate $(F 17 H)$ stained with Coomassie blue $(C B)$ and electrotransferred onto nitrocellulose for immunostaining with anti- $\beta$ tubulin $(\alpha-\beta T)$. The major $52 \mathrm{kDa}$ spot in both gels reacts strongly with the antibody.

$\mathrm{kDa}$. Furthermore, no radioactivity is detected in the aqueous phase at 40 and $46 \mathrm{kDa}$, and only a trace at $80 \mathrm{kDa}$. The radioautogram of the 2-dimensional gel of the oil phase (Fig. $3 B$ ) reveals that the 3 prominent phosphoproteins that partition into the TX-114 oil phase are indeed the major calcium/calmodulin- and C-kinase substrates of GCPs: pp40, pp46, and pp80ac (Katz et al., 1985).

\section{Distribution of radiolabel in the fetal brain after intraocular injection}

The radiolabeling of optic nerve growth cones in the brain must be done at the time of maximal outgrowth of optic nerve axons that have yet to reach their targets. This period of development is brief and is reported to be on or around day 15 or 16 of gestation in the rat, with a significant percentage of fibers having reached their destinations by F17 (Bunt et al., 1983). To confirm the time of optimal outgrowth anatomically, radioautography is performed on tissue sections from F15, F16, and F17 brains following eye injection with ${ }^{35} \mathrm{~S}$-methionine. After injection of F15 fetus ( $4 \mathrm{hr}$ survival), one observes only a thin, quickly tapering tract of labeled fibers, and the optic chiasm is poorly developed (data not shown). One day later (F16), the outgrowth of optic nerve fibers is much increased with the nerve maintaining its caliber as it approaches the now well-developed chiasm. The tract can be seen in Figure 4 crossing to the contralateral side and ascending on the lateral margin of the diencephalon. Following this ascending portion, the tract (most of which is destined to innervate the superior colliculus) becomes radioautographically undetectable over background at a point just rostral to the mesencephalon. Tissue more caudal or myelencephalic is clearly free of tract. In F17, a small but distinct tract can be seen extending all the way to the developing superior colliculus (data not shown).

\section{Proteins transported in the fetal optic nerve}

The injection of ${ }^{35} \mathrm{~S}$-methionine into fetal rat eyes results in appreciable introduction of the amino acid into the bloodstream. This is clear from the presence of counts in the homogenates of the (uninnervated) telencephalic and myelencephalic regions, respectively. Any attempt to determine the quantity of labeled material transported via the optic nerve to central brain tissue must first assess the degree of incorporation of blood-borne radioactivity (Fig. 5A; also see McEwen and Grafstein, 1968). To this end, ${ }^{35} \mathrm{~S}$-methionine is delivered to the circulation of F16 fetus by intraperitoneal injection. After a survival time of $4 \mathrm{hr}$, the brains of the injected animals are subdivided and fractionated as described, and quantitative analysis of incorporation is performed. An example of raw data and their numerical treatment is presented in the Appendix. The averaged ratios of incorporation from 4 such experiments are shown in Table 1. There is some variation, among the brain regions, in the relative proportions of radioactivity, most notable being the low figure for telencephalic GCP lysis supernatant (LYS). The relative specific incorporations (RSI) show a wide range of values among the various fractions, reflecting the different compartments of the neurons and glia contained in these fractions and the rates of turnover and transport into these compartments. However, the normalized RSI values across each fraction are remarkably similar for the 3 brain regions.

Table 2 presents the incorporation data from our intraocular injection (IO) experiments along side those from the intraperitoneal injection (IP) experiments described above, all expressed as ratios to the corresponding myelencephalic value (Fig. $5 B$; see Materials and Methods and Appendix). We use myelencephalon as our reference point because in both cases it receives all of its radiolabel via the systemic circulation, possessing no part of the optic tract. A comparison of intraocular and intraperitoneal injection results for telencephalon (Table 2) shows no significant difference in radiolabeling, as one would expect since it, as well, contains no optic tract. The lysed GCP (LGCP) fraction in particular is unchanged. In distinction, diencephalon, containing the elongating optic nerve, gives rise to several fractions showing significant increases in radioactivity after eye injection. Low-speed supernatant (LSS) is clearly enhanced after eye injection relative to the intraperitoneal injection value. Subfractionation of the low-speed supernatant shows the source of most of this enhancement to be the "O" fraction, containing soluble protein. The lysed GCP fraction possesses few absolute counts, but it displays the largest relative augment of counts of $77 \%$. In contrast, the soluble GCP lysis supernatant (bounded, prior to lysis, by the pelleted GCP) shows no increase. The "B" fraction exhibits a statistically insignificant increase, while the enhancement of the " $C$ " fraction is close to the margin of acceptance.

Table 3 displays ( $a$ and $b$ ) the relative specific incorporation (RSI) into subfractions of low-speed supernatant (LSS) after both intraocular (IO) and intraperitoneal (IP) injection, (c) the calculated relative specific incorporations for the radiolabel contributed by optic nerve, and (d) a balance sheet of this radioactivity. The relative specific incorporation values for intraperitoneal injection are from Table 1 and those for intraocular injection are calculated in the same manner. The differences between these values ( $c$ in Table 3 ) are the relative specific incorporations for the protein contributed by the optic nerve. The corresponding total counts, calculated by multiplying by the protein amounts listed in Table 1 , form a balance sheet for 


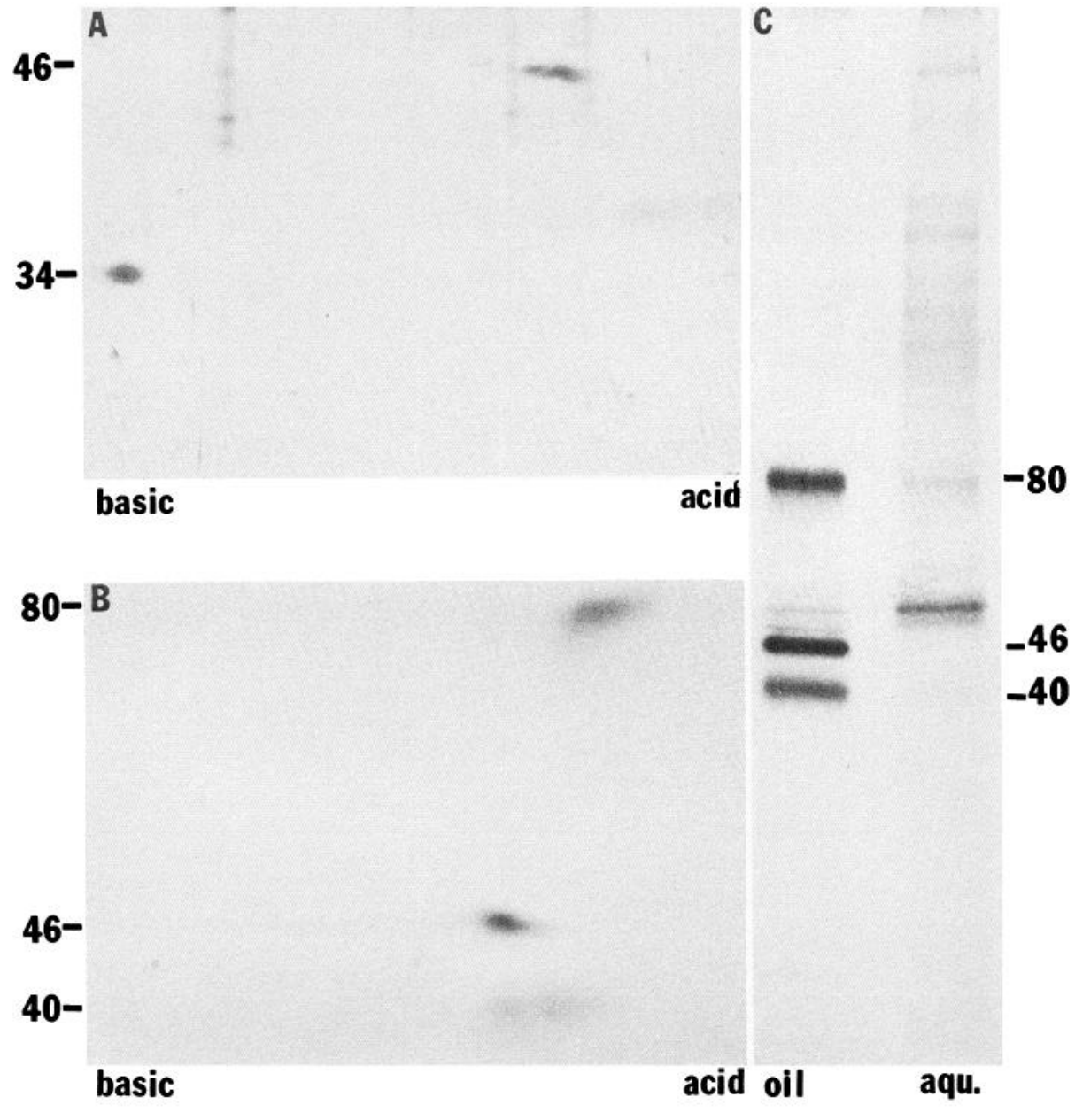

Figure 3. Triton X-114 extraction of lysed GCPs. A, Silver-stained 2-dimensional IEF gel (detail) of oil phase. The only 2 major polypeptides detected are pp46 (note microheterogeneity) and p34. $B$ and $C$, Radioautograms of phosphoproteins $\left(\mathrm{Ca}^{2+}\right.$-stimulated phosphorylation). Note essentially complete partitioning of pp80ac, pp46, and pp40 into the oil phase (oil), whereas the aqueous phase ( $a q u$.) contains only one major band at about $53 \mathrm{kDa}$. pp80ac, pp46, and pp40 are resolved in 2 dimensions (IEF) in $B$. Markers at the left and right indicate molecular masses (in $\mathrm{kDa})$. the counts attributable to the material transported into and through the optic nerve ( $28 \%$ of radioactivity of the low-speed supernatant (LSS) is not accounted for). The relative specific incorporation (RSI) of protein contributed by the optic nerve shows that lysed GCP and "O" are the only 2 subfractions that receive a major contribution of counts from optic nerve. The low level of optic nerve counts in GCP lysis supernatant (LYS) is underlined here again. The numbers for this lysate and for fraction B (and perhaps C as well) are nonsignificant (or marginally significant) corresponding as they do to the uncertain differences between values for intraocular and intraperitoneal injection seen in Table 2. The significant increase in counts in lysed GCP after intraocular injection points to selective delivery of radioactivity via the optic tract to growth cone membranes.

Table 1. Incorporation of blood-borne ${ }^{35} \mathrm{~S}-$ methionine into fetal brain regions and recovery in subcellular fractions

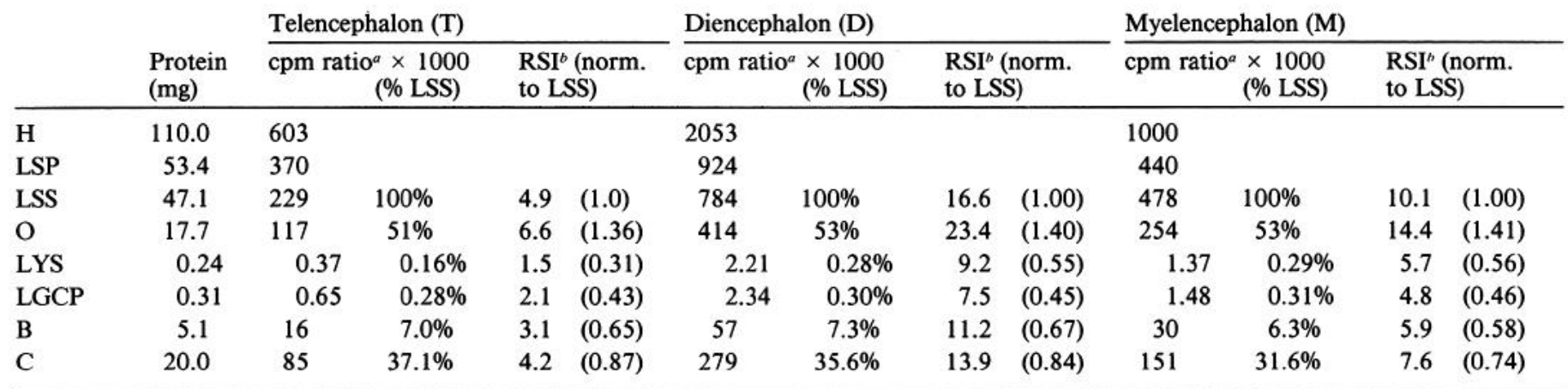

"Ratios of counts per minute (cpm) incorporated in the fractions of T, D, and M to the cpm incorporated into the homogenate (H) of M, averaged for 4 experiments. "Relative specific incorporation resulting from dividing $\mathrm{cpm}$ ratio $(\times 1000)$ by $\mathrm{mg}$ protein. The normalized figures (in parentheses) are provided to ease comparison. Because the fractionated samples include approximately equal amounts of carrier, the relative sizes of T vs D vs M are reflected in RSI. H, homogenate; LSP, lowspeed pellet; LSS, low-speed supernatant; O, high-speed supernatant; LYS, lysis supernatant of GCPs; LGCP, pelleted membranes of lysed GCPs; B and C, heavier fractions containing some GCPs and fragments of glia, neurites, and mitochondria. 


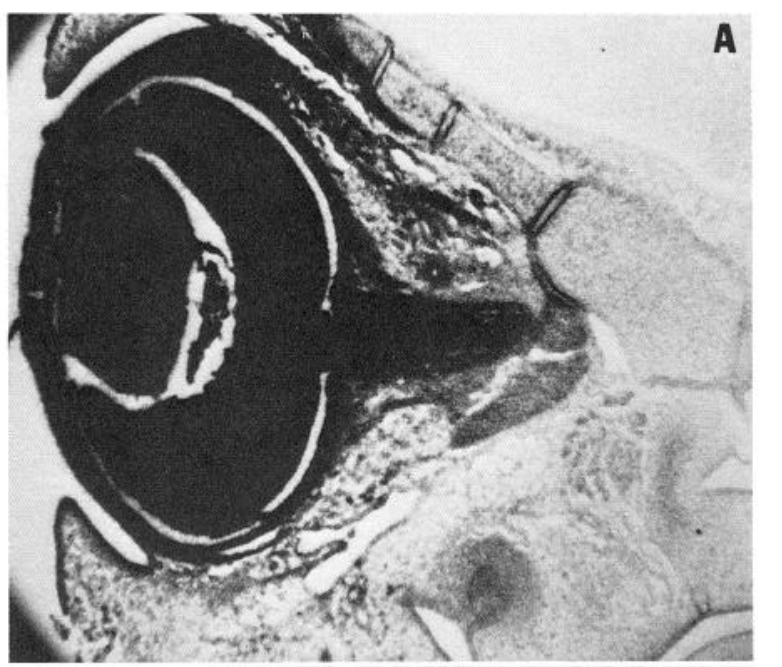

B

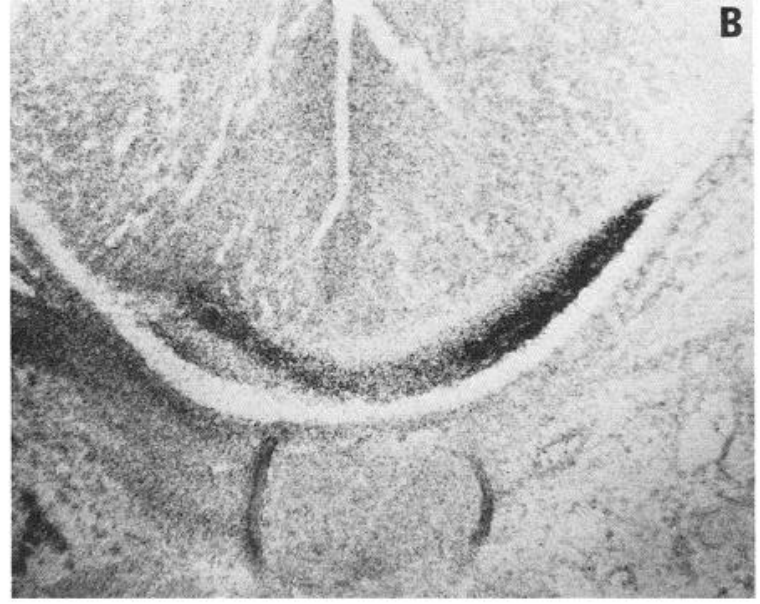

Figure 4. Light microscopic radioautography of $(A)$ fetal (F16) rat eye injected with ${ }^{35} \mathrm{~S}-\mathrm{L}-\mathrm{methionine}$ and $(B)$ diencephalon (upper half) and chiasm of the optic nerves of the same animal. Note intense labeling of the retina and the emerging optic nerve in $A$ and of the contralateral, ascending optic tract in $B . \times 50$.

\begin{tabular}{|c|c|c|c|c|}
\hline \multirow[b]{2}{*}{ Fraction } & \multicolumn{2}{|c|}{ Telencephalon } & \multicolumn{2}{|l|}{ Diencephalon } \\
\hline & $\mathrm{IO}$ & IP & $\mathrm{IO}$ & IP \\
\hline \multirow[t]{2}{*}{$\mathrm{H}$} & $0.66 \pm 0.19$ & $0.60 \pm 0.12$ & $2.42 \pm 0.26$ & $2.05 \pm 0.32$ \\
\hline & \multicolumn{2}{|c|}{$\Delta 0.06$ (ns) } & \multicolumn{2}{|c|}{$\Delta 0.37(18 \% ; p=0.28)$} \\
\hline \multirow[t]{2}{*}{ LSP } & $0.76 \pm 0.14$ & $0.84 \pm 0.16$ & $2.54 \pm 0.27$ & $2.01 \pm 0.31$ \\
\hline & \multicolumn{2}{|c|}{$\Delta 0.08$ (ns) } & \multicolumn{2}{|c|}{$\Delta 0.51(25 \% ; \mathrm{ns})$} \\
\hline \multirow[t]{2}{*}{ LSS } & $0.62 \pm 0.26$ & $0.48 \pm 0.10$ & $2.58 \pm 0.25$ & $1.64 \pm 0.03$ \\
\hline & \multicolumn{2}{|c|}{$\Delta 0.14(\mathrm{~ns})$} & \multicolumn{2}{|c|}{$\Delta 0.94(57 \% ; p<0.01)$} \\
\hline \multirow[t]{2}{*}{$\mathrm{O}$} & $0.72 \pm 0.24$ & $0.46 \pm 0.04$ & $2.67 \pm 0.35$ & $1.63 \pm 0.13$ \\
\hline & \multicolumn{2}{|c|}{$\Delta 0.26(\mathrm{~ns})$} & \multicolumn{2}{|c|}{$\Delta 1.04(64 \% ; p<0.05)$} \\
\hline \multirow[t]{2}{*}{ LYS } & $0.34 \pm 0.03$ & $0.27 \pm 0.08$ & $1.74 \pm 0.16$ & $1.62 \pm 0.34$ \\
\hline & \multicolumn{2}{|c|}{$\Delta 0.07$ (ns) } & $\Delta 0.12(\mathrm{~ns})$ & \\
\hline \multirow[t]{2}{*}{ LGCP } & $0.45 \pm 0.13$ & $0.44 \pm 0.04$ & $2.79 \pm 0.42$ & $1.58 \pm 0.26$ \\
\hline & \multicolumn{2}{|c|}{$\Delta 0.01(\mathrm{~ns})$} & \multicolumn{2}{|c|}{$\Delta 1.21(77 \% ; p=0.05)$} \\
\hline B & \multicolumn{2}{|c|}{$\Delta-0.02(\mathrm{~ns})$} & \multicolumn{2}{|c|}{$\Delta 0.32(17 \% ; p=0.15)$} \\
\hline $\mathrm{C}$ & \multicolumn{2}{|c|}{$\Delta-0.08(\mathrm{~ns})$} & \multicolumn{2}{|c|}{$\Delta 0.33(18 \% ; p=0.10)$} \\
\hline
\end{tabular}

The adjusted, corrected cpm for the fractions of $\mathrm{T}$ and $\mathrm{D}$ were divided by the corresponding $\mathrm{cpm}$ for the fractions of $\mathrm{M}$. This calculation is explained in detail, with examples, in the Appendix. Figures above are the averages over several experiments. $\Delta$, difference between IO (intraocular) and IP (intraperitoneal) injection. $p$ values 0.25 or greater are listed as "not significant" (ns). An exception is made for diencephalon homogenate because, in fact, this is an increase in its counts not borne out by the statistics. H, homogenate; LSP, low-speed pellet; LSS, low-speed supernatant; O, high-speed supernatant; LYS, lysis supernatant of GCPs; LGCP, pelleted membranes of lysed GCPs; B and C, heavier fractions containing some GCPs and fragments of glia, neurites, and mitochondria.

\section{Optic nerve-derived polypeptides of lysed GCP}

Lysed GCP fractions isolated from diencephalon and myelencephalon of F16 fetal brain after eye injection are analyzed by SDS-PAGE (equal amounts of protein loaded) and fluorography as illustrated in Figure 6 (F16). The patterns of incorporation into the constituent bands are qualitatively very similar in the 2 samples, but enhancement is seen in most bands and certainly all major ones of the diencephalic sample $(\mathrm{F} 16, \mathrm{e})$. The most prominently labeled species are those that show the most stain-
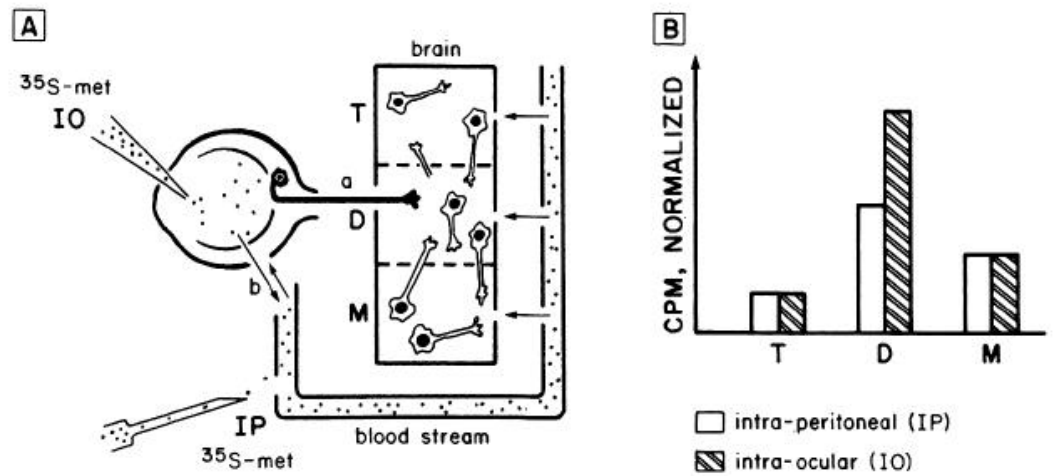

Figure 5. A, Schematic drawing depicting the 2 injections of radioisotope performed. Intraocular $(I O)$ injection into the fetal rate eye and 2 possible routes of radioactivity to the brain tissue subsequently fractionated: fast axonal transport down the sprouting optic nerve $(a)$ and leakage from the eye into the bloodstream $(b)$ and onward to the various brain regions. $I P$, injection into the peritoneum and the flow of radioactivity into all tissues. $T$, telecephalon; $D$, diencephalon; and $M$, myelencephalon. $B$, Bar graph showing the distribution of radioactivity in T, D, and $\mathrm{M}$ for IP and IO injections, normalized such that the amount of radioactivity in $\mathrm{M}$ is equal for both injections. The increase seen in D with IO injection is the amount contributed by axonal transport via the optic nerve. 

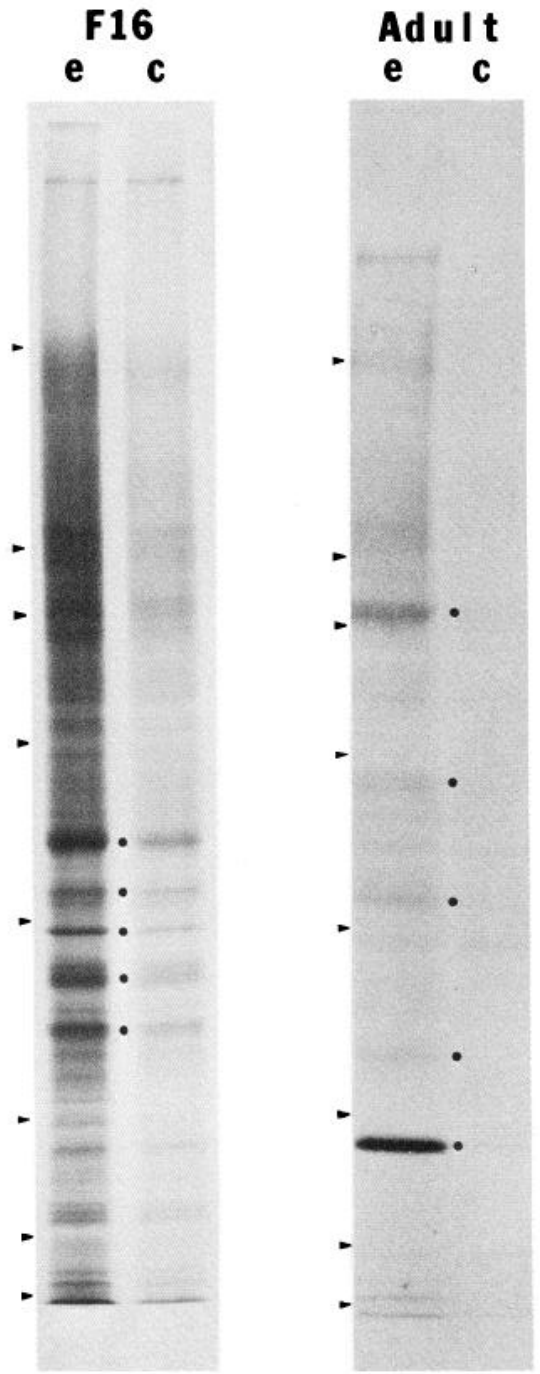

Figure 6. Fluorograms of lysed GCP (left, F16) and lysed synaptosome (right, adult) samples to compare labeling in experimental $(e)$ versus control $(c)$ samples. For lysed GCP, experimental and control samples are derived from diencephalon and myelencephalon, respectively; for synaptosomes, experimental material is prepared from lateral geniculate nuclei and superior colliculi, whereas control samples are from frontal cortex of the same animal. Equal protein aliquots were loaded for $(e)$ and $(c)$ for each experiment; furthermore, the amounts of radioactivity (about $7000 \mathrm{cpm}$ ) loaded in lanes F16, $e$ and Adult, $e$, as well as the exposure times, were identical. Gels are $5-15 \%$ polyacrylamide gradients. Molecular-weight markers are, from the bottom, 14, 20, 30, 43, $67,94,116$, and $210 \mathrm{kDa}$. Major labeled bands are indicated by dots. Note in both cases the significant enhancement of labeling in these bands comparing experimental and control samples.

ing by Coomassie blue, namely, 52, 46, 42, 38, and $34 \mathrm{kDa}$. A poorly defined region spread over the high-molecular-weight range $(80-220 \mathrm{kDa})$ also shows a significant increase in radioactivity although stained lightly by Coomassie blue (see Fig. 7). Three high-molecular-weight bands (at 112,125, and $300 \mathrm{kDa}$ ) are distinctive for being of nearly equal density in diencephalon and myelencephalon after subtracting the baseline densitometrically. ${ }^{2}$

\footnotetext{
${ }^{2}$ On the densitometric trace of this radioautogram the baseline is subtracted by connecting, with a line, troughs delimiting these peaks; then the areas above that line and enclosed by these peaks are measured using a digital graphics computer program.
}

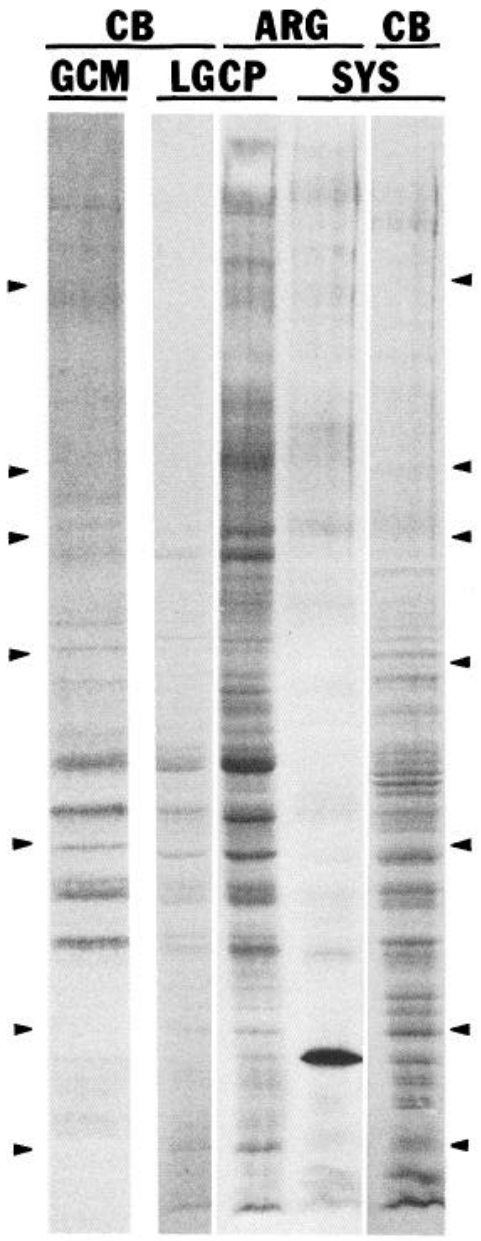

Figure 7. Autoradiographic $(A R G)$ comparison of radiolabeled polypeptides transported to diencephalic growth cone membranes (lysed GCP, LGCP; lane 3) and those transported to the adult presynaptic terminal membranes (SYS; lane 4) after eye injection at F16 and in the adult, respectively. Equal amounts of radioactivity were loaded in lysed GCP and SYS lanes, which were side by side in the same gel. Corresponding Coomassie blue-stained gel patterns $(C B)$ are shown in lanes 2 and 5. Lane 1 shows the Coomassie blue-stained gel pattern of GCM (salt-washed, saponin-treated) for comparison. Molecular-mass standards (arrows on both sides) are identical, from the bottom: 20,30,43, $67,94,116$, and $210 \mathrm{kDa}$.

\section{Polypeptides transported to the presynaptic ending}

Twelve hours after intraocular injection with ${ }^{35} \mathrm{~S}$-methionine, synaptosomes are prepared from the superior colliculi and lateral geniculate nuclei (and from a region of frontal cortex for control); the synaptosomal polypeptides are analyzed by SDSPAGE and fluorography. In our experiments the postinjection survival period allows protein species transported at rates of $>25 \mathrm{~mm} / \mathrm{d}$ to reach the sample tissue. "Background labeling" (control, frontal cortex) is minimal, and faint bands are discernible at 42,52 , and $98 \mathrm{kDa}$, the first 2 of these being, presumably, actin and tubulin (Fig. 6c). After $96 \mathrm{hr}$ of survival, one sees the above components as well as others with molecular weights of $28,35,48$, and $69 \mathrm{kDa}$ (Fig. 9). In the experimental (diencephalic) sample (Fig. $6 e$ ), radiolabeling is greatly increased above control. The polypeptides incorporating the most radiolabel migrate at $28,33,47,63$, and $100 \mathrm{kDa}$. The $28-\mathrm{kDa}$ moiety accounts for a significant portion of total counts in the 


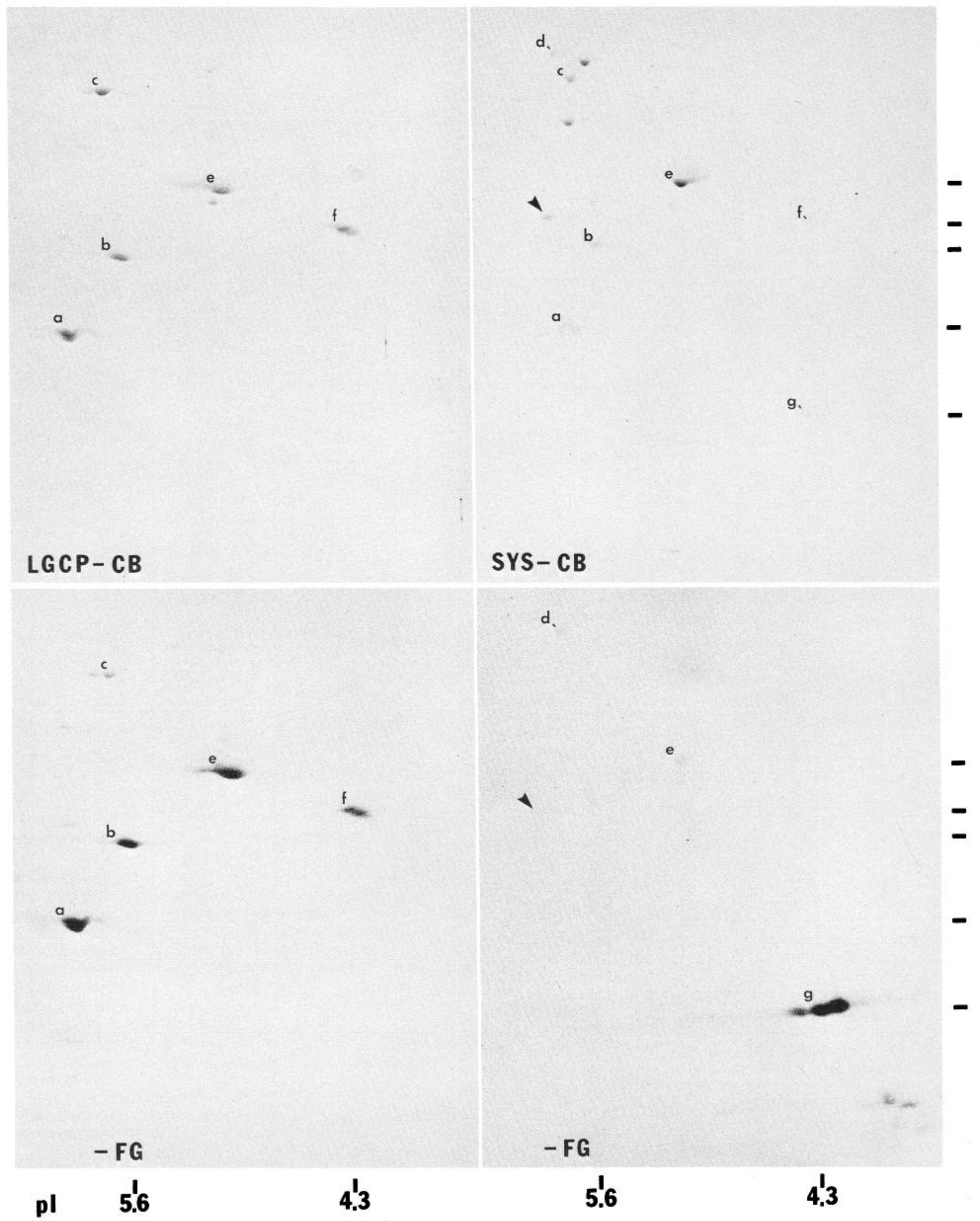

Figure 8. Comparison by 2-dimensional gel electrophoresis (IEF and SDS-PAGE) of major polypeptides in lysed GCPs ( $L G C P$ ) and synaptosomes $(S Y S)$. $-C B$ and $-F G$, staining patterns with Coomassie blue and fluorograms, respectively. The $\mathrm{pH}$ and $\mathrm{M}$, ranges included in the photographs are 4-7 and 20-150 kDa, respectively. All major stained and/or radiolabeled spots are found in the gel areas shown. The isoelectric points of pp46 and actin are indicated at the bottom of the figure for calibration. The markers at the right indicate apparent molecular weights (from top to bottom) of $52,46,42,34$, and $28 \mathrm{kDa}$. Small letters identify comigrating spots ( $b$, actin; $e$, tubulin). Some of these are very weak and, thus, difficult to reproduce photographically. Note the striking similarity of the LGCP-CB and LGCP-FG patterns. Most of these spots can also be seen in SYS$\mathrm{CB}$, but the $46 \mathrm{kDa}$ spot $(f)$ is barely visible (somewhat more prominent in other examples of this gel). Note the more alkaline polypeptide (arrowhead) with the same M, Overall, synaptosomal protein is distributed among a greater variety of polypeptides compared with lysed GCP protein. In SYS-FG, the majority of radioactivity is seen to be contained in a very acidic triplet of $28 \mathrm{kDa}$. Also prominent is a group of even more acidic, low-molecular-weight spots. None of these are seen in LGCP-FG. Tubulin (e), an unidentified spot $d$, and an alkaline $46 \mathrm{kDa}$ polypeptide (arrowhead) are clearly detectable. 
Table 3. Distribution of counts derived from optic nerve in subfractions of diencephalic LSS

\begin{tabular}{|c|c|c|c|c|}
\hline Fraction & $\begin{array}{l}\text { a } \\
\text { IO RSI } \\
\text { (cpm ratio } \\
\times 1000 / \\
\text { mg prot.) }\end{array}$ & $\begin{array}{l}\mathrm{b} \\
\text { IP RSI } \\
\text { (cpm ratio } \\
\times 1000 / \\
\text { mg prot.) }\end{array}$ & $\begin{array}{l}c(a-b) \\
\text { ON RSI } \\
\text { (cpm ratio } \\
\times 1000 / \\
\text { mg prot.) }\end{array}$ & $\begin{array}{l}d(c \times \text { prot. }) \\
\text { ON } \\
(c p m \text { ratio } \\
\times 1000)\end{array}$ \\
\hline LSS & 26.1 & 16.6 & 9.5 & $(100 \%)$ \\
\hline $\mathrm{O}$ & 38.3 & 23.4 & 14.9 & $(59 \%)$ \\
\hline LYS & 9.8 & 9.2 & 0.6 & $0.15(0.03 \%)$ \\
\hline LGCP & 13.2 & 7.5 & 5.7 & $1.80(0.40 \%)$ \\
\hline B & 13.1 & 11.2 & 1.9 & $9.7 \quad(2 \%)$ \\
\hline $\mathrm{C}$ & 16.4 & 13.9 & 2.5 & $51.0(11 \%)$ \\
\hline
\end{tabular}

Relative specific incorporations (RSI) in columns a and b are calculated as in Table 1, the figures in column b being taken from that table. "Cpm ratio" is the ratio of cpm incorporation into a particular fraction to that incorporated into the homogenate of myelencephalon. Keep in mind that the derived values for B and $\mathrm{C}$ correspond to non- or marginally significant differences (see Table 2 and text). IO, intraocular; IP, intraperitoneal injection. LSS, low-speed supernatant; $\mathrm{O}$, highspeed supernatant; LYS, lysis supernatant of GCPs; LGCP, pelleted membranes of lysed GCPs; B and C, heavier fractions containing some GCPs and fragments of glia, neurites, and mitochondria.

sample despite unimpressive staining by Coomassie blue (Figs. 7 and 9). Several other bands are seen but are much less prominent and/or are also present in the control sample in similar density; thus, they are disregarded. There is, in addition, a moderately labeled, poorly defined region of $118-128 \mathrm{kDa}$ that stains diffusely with Coomassie blue.

Figure 7 allows direct comparison of the 1-dimensional profiles of radiolabeled polypeptides from lysed GCP and lysed synaptosomes (SYS) (equal amounts of radioactivity loaded). The principal components incorporating ${ }^{35} \mathrm{~S}$-methionine are distinct in the 2 preparations. Specifically, the heavily labeled 34 , 38 , and $46 \mathrm{kDa}$ polypeptides of lysed GCPs are essentially absent from synaptosomes. Conversely, the prominent synaptosomal $28 \mathrm{kDa}$ band is not visible in lysed GCPs. Similarly, the other bands of synaptosomes mentioned above are barely detected in lysed GCPs.

Figure 8 compares by 2-dimensional gel electrophoresis (IEF, SDS-PAGE) polypeptides of lysed GCPs and synaptosomes stained by Coomassie blue and imaged by fluorography. The staining patterns of the 2 preparations appear to share several species, including the $34 \mathrm{kDa}$ polypeptide and, not surprisingly, actin and tubulin (a, b, and e in Fig. 8). In GCPs, the acidic 46 $\mathrm{kDa}$ polypeptide is not only a major stained species (Fig. 8, LGCP-CB) but also one of the most prominent spots in the fluorogram (Fig. 8, LGCP-FG). However, this polypeptide is just barely visible in the Coomassie blue-stained synaptosome gel (Fig. 8, SYS-CB) and is not detectable in the corresponding fluorogram (Fig. 7, SYS-FG). Interestingly, the fluorogram reveals in this molecular-weight region a more basic, faint spot (arrowhead) that may represent the weakly labeled $47 \mathrm{kDa}$ band seen in fluorograms of 1-dimensional gels. Other bands seen in the 1-dimensional fluorogram of synaptosomes are readily found in its 2-dimensional counterpart; these include the series of lowmolecular-weight species that have migrated below $28 \mathrm{kDa}$. On the other hand, we cannot unambiguously identify spots at 33 , 63 , or $100 \mathrm{kDa}$. This may be the result of the failure of these polypeptides to enter the gel or their being composed of several minor species of varying $\mathrm{p} I$. However, it can be clearly seen that no discernible radiolabel is in the regions of the major lysed GCP spots, with the exception of the faint $52 \mathrm{kDa}$, tubulin spot

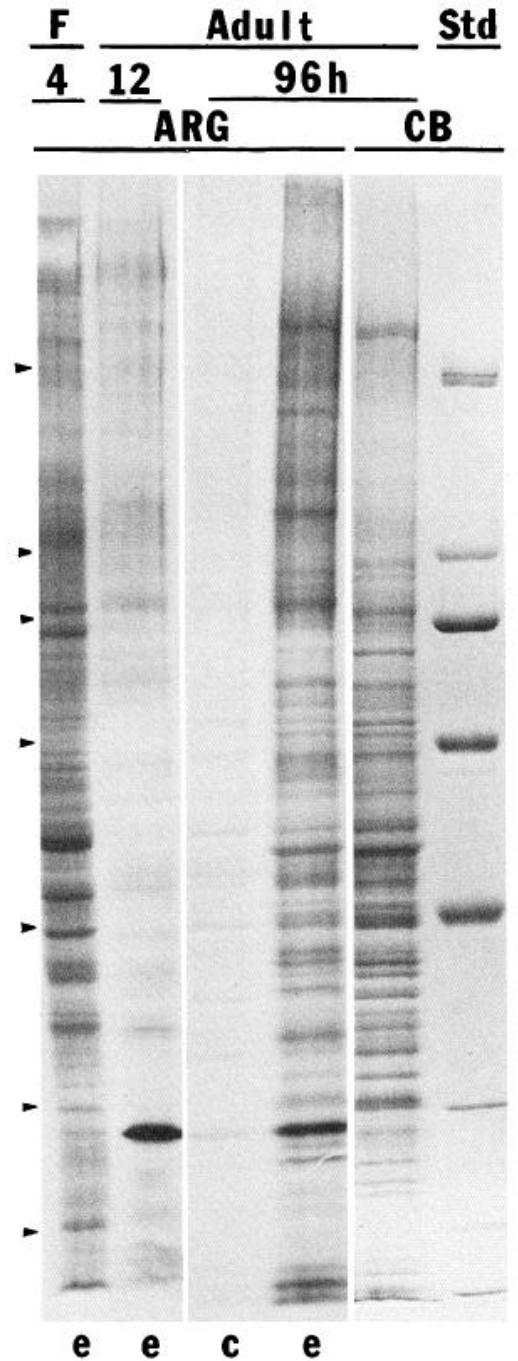

Figure 9. Comparison of radiolabeled polypeptides ( $A R G$, fluorography) of lysed GCPs ( $F$, fetal $4 \mathrm{hr}$ survival) with those observed in synaptosomes (Adult) after 12 and $96 \mathrm{hr}$ survival time following eye injection ( $e$, experimental tissues containing optic nerve and terminals; $c$, control, i.e., frontal cortex). Even after a $96 \mathrm{hr}$ survival postinjection, the pattern of labeled bands in control remains relatively faint and qualitatively different from that in the experimental sample (compare lanes 3 and 4). While $96 \mathrm{hr}$ survival leads to the labeling of many more species compared with $12 \mathrm{hr}$ survival (lane 4 vs. 2), the $96 \mathrm{hr}$ pattern remains distinct from the lysed GCP pattern, with the possible exception of the doublet at $38 \mathrm{kDa}$. For further explanations, see text. Lane 5 is the Coomassie blue $(C B)$ pattern of the fluorogram shown in lane 4; lane 6 contains molecular-weight standards $(20,30,43,67,94,116$, $210 \mathrm{kDa}$ ). The same standards are indicated by the arrowheads at the left. Equal amounts of radioactivity are loaded in lanes 1 and 2 and equal amounts of protein are loaded in lanes 3 and 4.

(e in Fig. 8). An additional spot of approximately $74 \mathrm{kDa}(\mathrm{d}$ in Fig. 8) is present in synaptosomes but not in lysed GCPs.

Given the possibility that transport and turnover rates might account for the major differences between lysed GCPs and synaptosomes, we allow some adult rats to survive $96 \mathrm{hr}$ postinjection. The resulting fluorographic pattern is shown in Figure 9. It is much more complex and includes added polypeptides migrating at $38,43,50$, and $68 \mathrm{kDa}$, and 5 species between 25 and $33 \mathrm{kDa}$. We do not know whether the $38 \mathrm{kDa}$ polypeptide arriving this late is identical to that seen in lysed GCP. No appreciable amount of $46 \mathrm{kDa}$ and only small amounts of 42 
and $52 \mathrm{kDa}$ label emerge after $96 \mathrm{hr}$ of survival; the 42 and 52 $\mathrm{kDa}$ bands are similar in density to those in the control pattern.

\section{Discussion}

One- and two-dimensional PAGE have shown that a membrane subfraction prepared from GCPs is enriched in a small number of major polypeptides. The data presented here address the following questions: (1) are these polypeptides true membrane components; (2) are they developmentally regulated, i.e., specifically associated with neurite growth; (3) how do they relate to known neuronal proteins; and (4) how does the polypeptide pattern change as a result of synaptogenesis?

\section{The transport paradigm}

In order to answer these questions, retinal ganglion cells are radiolabeled with the goal of analyzing proteins transported into the distal tips of growing or mature axons. The survival times ${ }^{3}$ of the animals used in the 2 experiments are selected so as to give preference to membrane proteins, which are rapidly transported to the cell periphery (Lasek, 1968). The use of this paradigm is essential for the study of presynaptic components because synaptosome fractions always contain substantial amounts of postsynaptic and nonsynaptic elements. The labeling experiments on the adult optic nerve have resulted in high specific activity in synaptosomes prepared from diencephalon relative to that for synaptosomes prepared from noninnervated control regions. Experiments on the growing optic nerve are more problematic. We sought to radiolabel the proteins transported to the tip of growing axons of retinal ganglion cells but found considerable counts in brain regions devoid of retinal ganglion axons. This is not due to diffusion from the injection site (1) because quantitative radioautography (data not shown) reveals no rostrocaudal labeling gradient starting near the eye, and (2) because ${ }^{35} \mathrm{~S}$-labeling of protein from the telencephalon is not increased relative to that from the myelencephalon. Leakage of ${ }^{35} \mathrm{~S}-\mathrm{me}$ thionine from the eye into the bloodstream and subsequent systemic labeling of neurons and other cells is therefore the most likely explanation. This "nonspecific" labeling can be mimicked by intraperitoneal injection of the radioactivity, and the resulting data can be used to calculate the contribution made by systemically delivered counts to radioactivity recovered from diencephalon after eye injection (see Fig. 5). The difference is the radiolabeled material contributed by the optic nerve. That the percentage of this material recovered in the GCP fraction is small (see Table 3) points to several facts: (1) Anatomically, the growth cone constitutes, in the case of the F16 optic nerve, perhaps the final $0.1 \%$ of the axon. (2) Axon shafts and their fragments are found especially in fraction $\mathrm{C}$ (see Pfenninger et al., 1983); accordingly, a significant portion of the radioactivity should be found in this fraction. (3) Soluble proteins contained within the more proximal neurite are released upon homogenization and are found in the " $O$ " fraction; their presence in such quantities distal to the chiasm after only $4 \mathrm{hr}$ survival is consistent with the observation that these proteins (soluble and, therefore, presumably transported slowly) are transported at an accelerated "slow rate" characteristic of the growing neuron (see below). Optic nerve growth cones are few relative to those

\footnotetext{
${ }^{3}$ Survival times, although not completely comparable, are selected so that most rapidly transported proteins have reached the axonal tips in both cases, taking into consideration the different lengths of the optic axons. Thus, comparison of growth cone and presynaptic labeled membrane proteins is feasible.
}

tipping the axons of the many other sprouting neurons at this stage, setting a limit on the possible degree of enrichment of radioactivity from the retinal ganglion cells in the GCP fraction of the diencephalon. However, the percentage increase in protein radioactivity, contributed by axons of the optic nerve, is significant and is greatest in crude growth cone membranes (Table 3).

\section{Membrane proteins of GCPS}

In a previous paper (Ellis et al., 1985b), we have shown that the subfractionation of membranes from GCPs results in a simple pattern of 5 major polypeptides. Washing the membranes at high ionic strength leads to the enrichment of 2 polypeptide doublets $\left(\mathbf{M}_{r}=38\right.$ and $\left.34 \mathrm{kDa}\right)$ as seen in 1-dimensional SDSpolyacrylamide gels. We confirm here, by 2 -dimensional gel electrophoresis, the relative simplicity of the GCM polypeptide pattern, as well as the enrichment of the $34 \mathrm{kDa}$ species. However, the $38 \mathrm{kDa}$ doublet is difficult to see in 2-dimensional gels using either IEF or NEPHGE in the first dimension. It may fail to focus or may not enter the first-dimension gel.

Of the 3 remaining major bands detected in 1-dimensional gcls with Coomassie blue or silver, 2 (52 and $42 \mathrm{kDa}$ ) have equivalents in the soluble GCP subfraction and comigrate with tubulin and actin, respectively. Two-dimensional gel analysis performed under various conditions ${ }^{4}$ and, in the case of tubulin, western blot analysis with an anti-tubulin antibody further confirm this observation. Therefore, it is highly likely that the 52 and $42 \mathrm{kDa}$ species in the GCM preparation consist to a large extent of tubulin and actin, respectively. The presence of a membrane form of tubulin and the synthesis of tubulin on free as well as membrane-associated ribosomes has been suggested (Soifer and Czosnek, 1980). However, it appears just as likely that some portion of both actin and tubulin, which are abundant in GCPs, remains indirectly attached to membranes even after extensive washing with high salt in the presence of mild detergent (Hubbard and Ma, 1983).

SDS-PAGE analysis shows a fifth major band in the GCM preparation at approximately $46 \mathrm{kDa}$. While the lysis supernatant contains a band migrating at the same $\mathrm{M}_{r}, 2$-dimensional gel analysis now reveals that an acidic $46 \mathrm{kDa}$ GCM polypeptide is highly enriched in GCM membranes and absent from the lysis supernatant. In favorable 2-dimensional gels this acidic polypeptide ( $\mathrm{p} I 4.3$ ) is resolved into 3 closely spaced charge variants, and it comigrates with a major phosphoprotein of GCPs, the substrate of a calcium/calmodulin-dependent protein kinase and of C-kinase (Katz et al., 1985; Hyman and Pfenninger, 1987). Both proteins become enriched further in membranes washed in the presence of high salt concentrations and partition into the oil phase of TX-114 extracts. No protein or ${ }^{32} \mathrm{P}$ label are detectable in the salt wash or the aqueous phase of TX-114 (see Dosemeci and Rodnight, 1987). Furthermore, the 2 polypeptides are prevalent in growing but not in mature neurons (see below and Katz et al., 1985). Thus, the major membrane protein and the phosphoprotein are believed to be the same species and will be called pp46. In the meantime, pp46 and GAP43 have been shown to comigrate in 2 dimensions, to share immunochemical determinants and to contain the same

\footnotetext{
${ }^{4}$ Drs. G. May and J. Rosenbaum of Yale University generously ran our GCP and GCM polypeptides in their isoelectric focusing/SDS-PAGE system and also found that our 52 and $42 \mathrm{kDa}$ species comigrate with tubulin and actin, respectively.
} 
phosphopeptides after V8 protease digestion (Meiri et al., 1986; see also De Graan et al., 1985; Skene et al., 1986). Furthermore, pp46 and $\mathrm{Fl}$, the hippocampal synaptic protein phosphorylated in parallel with long-term potentiation (Routtenberg et al., 1985), have bcen shown to bc indistinguishable based on a varicty of parameters (Nelson et al., 1989). This is consistent with a numher of other reports that pp46, GAP43, F1 and B50 are all the same polypeptide (Pfenninger, 1986; Benowitz and Routtenberg, 1987; Neve et al., 1987; Snipes et al., 1987).

The identity of these proteins is of great biological interest but presents a conflict. Most biochemical data on GAP43/F1/ B50 are based on a polypeptide isolated by extraction at high pH or from the aqueous TX-114 phase (Oestreicher et al., 1983; Basi et al., 1987; Benowitz et al., 1987). Accordingly, sequence data reveal a highly hydrophilic protein without any hydrophobic region (Basi et al., 1987; Karns et al., 1987). In contrast, growth cone pp46 behaves entirely like an integral membrane protein. Perhaps most likely, the sources used for isolation of GAP43/B50/F1 contain a second, comigrating and growth-related protein that is different from pp46, or the isolated protein is a cytosolic fragment of a larger membrane protein, perhaps pp46. In any case, it is unlikely that the published deduced sequence data are those of pp46.

The results of TX-114 extraction suggest that $\mathrm{p} 34$ is a probable integral membrane protein like pp46. Phosphorylated pp $80 \mathrm{ac}$ and pp 40 are also found primarily or exclusively in the oil phase of the extract. This is surprising in view of the fact that these phosphoproteins have been detected in GCP cytosol (Katz et al., 1985). These proteins may be capable of moving back and forth hetween cytosol and membrane, perhaps in a phosphorylation-controlled manner.

\section{The major polypeptides of GCPs are developmentally regulated}

As already discussed, intraocular injection in the fetus results in a significant increase in the counts recovered from lysed diencephalic GCPs. As analyzed by fluorography of 1-dimensional gels, this increase in radioactivity is evident in the major polypeptide bands of GCP membranes. Enhancement in radioactivity is also found as a smear between approximately 60 and $180 \mathrm{kDa}$, an area that we now know to contain a large number of minor membrane glycoproteins (Greenberger and Pfenninger, 1986). The pattern of radiolabeled major bands overlaps precisely with that of GCM polypeptides in 1- and 2-dimensional gels, indicating that these polypeptides are synthesized by retinal ganglion cells and rapidly transported to the distal ends of the growing axons. While this finding may be expected for bona fide membrane proteins, it is somewhat surprising for the presumably soluble 52 and $42 \mathrm{kDa}$ species. However, some workers have demonstrated that slow axoplasmic transport is accelerated in growing or regenerating neurons (Droz and Leblond, 1963; Lasek, 1970; Marchisio et al., 1973).

The pattern of synaptosomal polypeptides labeled after intraocular injection is dramatically different from that obtained from GCPs. After a survival time adjusted to allow for the rapid transport of newly synthesized materials into the nerve ending, the major GCM protein species are virtually undetectable under our experimental conditions. This includes pp 46 , as one would expect from its identity with GAP43 (Skene and Willard, 1981a, b; Willard et al., 1985; see also Theiler and McClure, 1978; Benowitz et al., 1983). The close proximity of pp46 and the synaptosomal band at $47 \mathrm{kDa}$ (in 1-dimensional gels) requires the resolution of these polypeptides in 2 dimensions to confirm that they are, in fact, discrete species. In the synaptosome gels, the region of pp46 exhibits no fluorographically detectable radioactivity, while a small amount of label is present in a polypcptide of approximatcly that size at a morc basic $p I$. (If the survival time postinjection is increased to $96 \mathrm{hr}$, many more polypeptide bands are labeled, but they still do not match up with those observed in GCMs, with the possible exception of a band at $38 \mathrm{kDa}$.) Overall, it follows from this comparison that the rates of synthesis, turnover, and/or anterograde axoplasmic transport of the major GCP membrane proteins, as well as those of the 52 and $42 \mathrm{kDa}$ bands (presumably tubulin and actin, respectively), are dramatically decreased in the adult nervous system. Although we do not have data on the neuronal perikarya to confirm this conclusion, it is likely, therefore, that the major GCM polypeptides are growth-associated proteins.

\section{Maturation of the nerve ending}

The comparison of GCP and synaptosome labeling patterns following intraocular injection shows not only that the synthesis of a series of proteins is turned down at or after synaptogenesis but also that a few polypeptides that were previously not present or difficult to detect are now prominent. These include, in particular, the $28 \mathrm{kDa}$ polypeptide and other, less prominent species at $33,47,63$, and $100 \mathrm{kDa}$. Direct comparison with earlier results on protein transport into synaptosomes is difficult because molecular weight calibrations are not available (see introductory remarks). The work of Levine and Willard (1980) and of the laboratories of Lasek $(1968,1970)$ and Grafstein and Murray (1969) has defined the various groups of transported proteins in the optic system without synaptosome isolation. The following agreements and discrepancies can be noted. Clearly, our heavily labeled $28 \mathrm{kDa}$ band corresponds to the prominent $29 \mathrm{kDa}$ band that arrives at the superior colliculus as part of group I (Levine and Willard, 1980). Three proteins in the superior colliculus migrate at 47,63 , and $100 \mathrm{kDa}$ and may correspond to our more heavily labeled synaptosomal species. The $120 \mathrm{kDa}$ band from group I is present in our preparation but not in the same abundance. Among the group II polypeptides, the 53 and $56 \mathrm{kDa}$ pair is visible in small quantity at the terminal. However, the $95,160,200$, and $220 \mathrm{kDa}$ proteins cannot be identified positively in the synaptosomal membranes. The discrepancies here noted are consistent with a more specialized composition of the synaptic nerve terminal.

In conclusion, neuronal synthesis and/or export into the axon of the major polypeptides of growth cone membranes is developmentally regulated: while they are prevalent in the growing axon, the rates of synthesis and/or axoplasmic transport of these polypeptides are greatly diminished in the mature nervous system. Around or after the time of synaptogenesis, the neuron switches synthesis and/or export into the axon to other species, in particular, a polypeptide of $28 \mathrm{kDa}$. The identification and further characterization of such developmentally regulated proteins is of importance for studies on control mechanisms of axonal growth and synaptogenesis.

\section{Appendix}

The raw data from a representative intraocular injection experiment are displayed in Table 4 , followed by the calculations performed in order to derive the normalized ratios presented in Table 2, under Results.

In order to correct for (1) the error introduced by the variable yield of a subfraction and (2) the error introduced by the unequal addition of cold carrier tissue to the sample just prior to homogenization, the 
Table 4. Raw total counts

\begin{tabular}{lccc} 
& $\begin{array}{l}\text { Telencephalon } \\
(\mathrm{T}) \\
\left(\mathrm{cpm} \times 10^{-3}\right)\end{array}$ & $\begin{array}{l}\text { Diencephalon } \\
(\mathrm{D}) \\
\left(\mathrm{cpm} \times 10^{-3}\right)\end{array}$ & $\begin{array}{l}\text { Myelencephalon } \\
(\mathrm{M}) \\
\left(\mathrm{cpm} \times 10^{-3}\right)\end{array}$ \\
\hline H & 21,500 & 106,700 & 40,600 \\
LSP & 12,800 & 50,300 & 18,500 \\
LSS & 8310 & 53,900 & 21,500 \\
O & 2850 & 13,800 & 6300 \\
LYS & 9 & 74 & 54 \\
LGCP & 20 & 183 & 72 \\
B & 233 & 1828 & 1113 \\
C & 1621 & 9516 & 5396
\end{tabular}

H, homogenate: LSP, low-speed pellet; LSS, low-speed supernatant; O, B, C, LSS subfractions O, B, C; LYS, GCP lysis supernatant; LGCP, lysed GCP.

following 2 steps are carried out: First, the total counts for a particular sample are divided by the total protein in that sample to give specific activities. Second, this specific activity is adjusted to account for the small but often significant variations in total homogenate protein among the 3 fractionations (telencephalon, diencephalon, and myelencephalon) of a single experiment. This second step is performed by multiplying the specific activities of the subfractions of telencephalon and diencephalon by the ratios of total homogenate protein of myelencephalon to that of telencephalon and diencephalon, respectively. These 2 arithmetic manipulations are algebraically equivalent to multiplying by factor $F$ described under Materials and Methods. The calculations are illustrated in Table 5 for the GCP subfractions, LGCP, and LYS.

The resulting adjusted specific activities from telencephalon and diencephalon are then divided by that from myelencephalon to form ratios. Expressing the data in this way allows us to average the results from experiments with diverging total incorporation of radioactivity. Averaging the actual incorporated counts across experiments would give undue weight to the result of experiments in which more ${ }^{35} \mathrm{~S}$-methionine was delivered to the retinal ganglion cells. The values obtained by this calculation are shown in Table 6 (intraocular injection).

Ratios thus derived for each subfraction are compiled from the eye injection experiments, and the same is done separately for the intraperitoneal injection experiments. The averaged values for these ratios are listed in Table 2.

\section{References}

Basi, G. S., R. D. Jacobson, I. Virag, J. Schilling, and J. H. P. Skene (1987) Primary structure and transcriptional regulation of GAP-43, a protein associated with nerve growth. Cell 49: 785-791.

Benowit, L. I., and A. Routtenberg (1987) A membrane phosphoprotein associated with neural development, axonal regeneration, phospholipid metabolism, and synaptic plasticity. Trends Neurosci. 10: 527-532.

Benowitz, L. I., M. G. Yoon, and E. R. Lewis (1983) Transported.
Table 6. Ratios of adjusted specific activities

\begin{tabular}{lll} 
& $\mathrm{T} / \mathrm{M}$ & $\mathrm{D} / \mathrm{M}$ \\
\hline LYS & 0.175 & 1.555 \\
LGCP & 0.304 & 2.876 \\
\hline
\end{tabular}

T, telencephalon; $\mathrm{M}$, myelencephalon; $\mathrm{D}$, diencephalon.

proteins in the regenerating optic nerve: Regulation by interactions with the optic tectum. Science 222: 185-188.

Benowitz, L. I., N. I. Perrone-Bizzozero, and S. P. Finklestein (1987) Molecular properties of the growth-associated protein GAP-43 (B50). J. Neurochem. 48: 1640-1647.

Bordier, C. (1981) Phase separation of integral membrane proteins in Triton X-114 solution. J. Biol. Chem. 256: 1604-1607.

Bradford, M. M. (1976) A rapid and sensitive method for the quantification of microgram quantities of proteins utilizing the principle of protein-dye binding. Anal. Biochem. 72: 248-254.

Bunt, S. M., R. D. Lund, and P. W. Land (1983) Prenatal development of the optic projection in albino and hooded rats. Dev. Brain Res. 6: 149-168.

Cancalon, P., and J.S. Elam (1980) Rate of movement and composition of rapidly transported proteins in regenerating olfactory nerve. $\mathbf{J}$. Neurochem. 35: 889-897.

Carton, H. C., and S. H. Appel (1973) The contribution of axoplasmic flow in optic nerve and protein synthesis within the optic tectum to synaptic membrane proteins of the chick optic tectum. J. Neurochem. 20: $1707-1717$.

Castle J. D., and G. E. Palade (1978) Secretion granules of the rabbit parotid. Selective removal of secretory contaminants from granule membranes. J. Cell Biol. 76: 323-340.

Cohen, R. S., F. Blomberg, K. Berzins, and P. Siekevitz (1977) The structure of post-synaptic densitics isolated from dog cerebral cortex. I. Overall morphology and protein composition. J. Cell Biol. 74: 181203.

De Graan, P. N. E., C. O. M. Van Hooff, B. C. Tilly, A. B. Oestreicher, P. Schotman, and W. H. Gispen (1985) Phosphoprotein B-50 in nerve growth cones from fetal rat brain. Neurosci. Lett. 61: 235-241.

Dosemeci, A., and R. Rodnight (1987) Demonstration by phase-partitioning in Triton X-114 solutions that phosphoprotein B-50 (F-1) from rat brain is an integral membrane protein. Neurosci. Lett. 74: 325-330.

Droz, B., and C. P. Leblond (1963) Axonal migration of proteins in the central nervous system and peripheral nerves as shown by radioautography. J. Comp. Neurol. 121: 325-346.

Ellis, L., F. Katz, and K. H. Pfenninger (1985a) Nerve growth cones isolated from fetal rat brain. II. Cyclic adenosine $3^{\prime}: 5^{\prime}$-monophosphate (cAMP)-binding proteins and cAMP-dependent protein phosphorylation. J. Neurosci. 5: 1393-1401.

Ellis, L., I. Wallis, E. Abreu, and K. H. Pfenninger (1985b) Nerve growth cones isolated from fetal rat brain. IV. Preparation of a membrane subfraction and identification of a membrane glycoprotein expressed on sprouting neurons. J. Cell Biol. 101: 1977-1989.

Fujiki, Y., A. L. Hubbard, S. Fowler, and P. B. Lazarow (1982) Iso-

Table 5. Adjusted specific activities

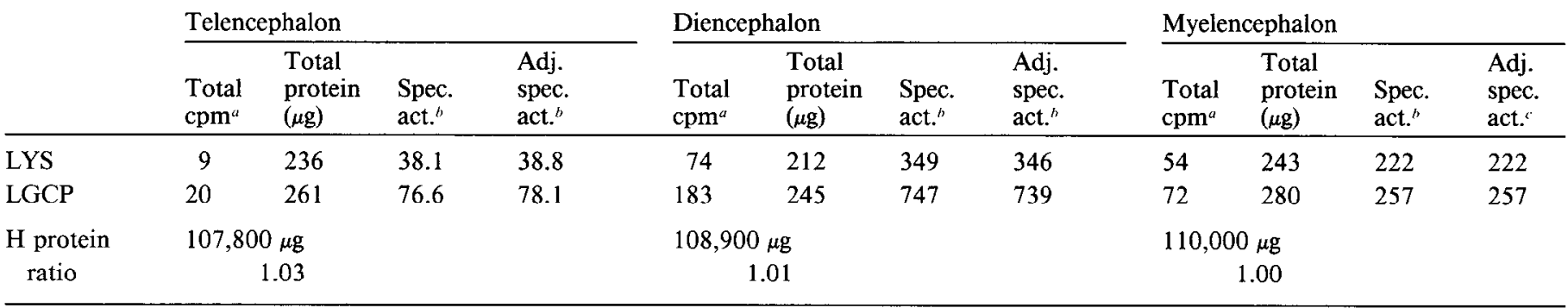

\footnotetext{
"Total $\mathrm{cpm} \times 10^{-3}$.

"Specific activity and adjusted specific activity, $\mathrm{cpm} / \mu \mathrm{g}$ protein.

${ }^{c} \mathrm{cpm} / \mu \mathrm{g}$ protein; because the ratio is 1.00 in this case, these values equal those of the specific activity.
} 
lation of intracellular membranes by means of sodium carbonate treatment: Application to endoplasmic reticulum. J. Cell Biol. 93: 97-102.

Garner, J., and H. Mahler (1982) Biogenesis and maintenance of presynaptic macromolecules. Soc. Neurosci. Abst. 8: 493.

Gordon-Weeks, P., and O. Lockerbie (1984) Isolation and partial characterization of neuronal growth cones from neonatal rat forebrain. Neuroscience 13: 119-136.

Grafstcin, B., and D. S. Forman (1980) Intraccllular transport in ncurons. Physiol. Rev. 60: 1167-1283.

Grafstein, B., and M. Murray (1969) Transport of proteins in goldfish optic nerve during regeneration. Exp. Neurol. 25: 494-508.

Greenberger, L. M., and K. H. Pfenninger (1986) Membrane glycoproteins of the nerve growth cone: Diversity and growth regulation of oligosaccharides. J. Cell Biol. 103: 1369-1382.

Hawkes, R., E. Niday, and J. Gordon (1982) A dot-immunobinding assay for monoclonal and other antibodies. Anal. Biochem. 119:142147.

Hubbard, A. L., and A. Ma (1983) Isolation of rat hepatocyte plasma membranes, II. Identification of membrane-associated cytoskeletal proteins. J. Cell. Biol. 96: 230-239.

Hyman, C., and K. H. Pfenninger (1987) Intracellular regulators of neuronal sprouting: Protein and lipid phosphorylation in a fraction of nerve growth cones isolated from fetal rat brain. J. Neurosci. 7: 4076-4083.

Karns, L. R., N. G. Shi-Chung, J. A. Freeman, and M. C. Fishman (1987) Cloning of complementary DNA for GAP-43, a neuronal growth-related protein. Science 236: 597-600.

Katz, F., L. Ellis, and K. H. Pfenninger (1985) Nerve growth cones isolated from fetal rat brain: III. Calcium-dependent protein phosphorylation. J. Neurosci. 5: 1402-1411.

Laemmli, U. K. (1970) Cleavage of structural proteins during the assembly of the head of bacteriophage T4. Nature 227: 680-685.

Lasek, R. (1968) Axoplasmic transport in cat dorsal root ganglion

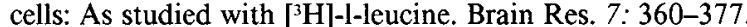

Lasek, R. J. (1970) Axonal transport of proteins in dorsal root ganglion cells of the growing cat: A comparison of growing and mature neurons. Brain Res. 20: 121-126.

Levine, J., and M. Willard (1980) the composition and organization of axonally transported proteins in the retinal ganglion cells of the guinea pig. Brain Res. 194: 137-154.

Marchisio, P. C., J. Sjostrand, M. Aglietta, and J.-O. Karlsson (1973) The development of axonal transport of proteins and glycoproteins in the optic pathway of chick embryos. Brain Res. 63: 273-284.

Marko, P., J. P. Susz, and M. Cuenod (1971) Synaptosomal proteins and axoplasmic flow: Fractionation by SDS polyacrylamide gel electrophoresis. FEBS Lett. 17: 261-264.

McEwen, B. S., and B. Grafstein (1968) Fast and slow components in axonal transport of protein. J. Cell Biol. 38: 494-508.

Meiri, K. F., K. H. Pfenninger, and M. B. Willard (1986) Growthassociated protein, GAP-43, a polypeptide that is introduced when neurons extend axons, is a component of growth cones and corresponds to pp46, a major polypeptide of a subcellular fraction enriched in growth concs. Proc. Natl. Acad. Sci. USA 83: 3537-3541.

Morrissey, J. H. (1981) Silver stain for proteins in polyacrylamide gels: A modified procedure with enhanced uniform sensitivity. Anal. Biochem. 117: 307-310.

Nelson, R. B., D. J. Linden, C. Hyman, K. H. Pfenninger, and A. Routtenberg (1989) The two major phosphoproteins in growth cones are probably identical to two protein kinase C substrates correlated with persistence of long-term potentiation. J. Neurosci. 9: 381-389.

Neve, R. L., N. I. Perrone-Bizzozero, S. Finklestein, H. Zwiers, E. Bird, D. M. Kurnit, and L. I. Benowitz (1987) The neuronal growthassociated protein GAP-43 (B-50, F1): Neuronal specificity, developmental regulation and regional distribution of the human and rat mRNAs. Mol. Brain. Res. 2: 177-183.

Oestreicher, A. B., C. J. Van Dongen, H. Zwiers, and W. H. Gispen (1983) Affinity-purified anti-B-50 protein antibody: Interference with the function of the phosphoprotein B-50 in synaptic plasma membranes. J. Neurochem. 41: 331-340.
O'Farrell, P. Z. (1975) High resolution two-dimensional electrophoresis of proteins. J. Biol. Chem. 250: 4007-4021.

O'Farrell, P. Z., H. M. Goodman, and P. H. O’Farrell (1977) High resolution two-dimensional electrophoresis of basic as well as acidic proteins. Cell 12: 1133-1142.

Pfenninger, K. H. (1986) Of nerve growth cones, leukocytes and memory: On the growth cone's second messenger systems and growthregulated proteins. Trends Neurosci. 9: 562-565.

Pfenninger, K. H., L. Ellis, M. P. Johnson, L. B. Friedman, and S. Somlo (1983) Nerve growth cones isolated from fetal rat brain. I. Subcellular fractionation and characterization. Cell 35: 573-584.

Piperno, G., and D. J. L. Luck (1977) Microtubular proteins of Chlamydomonas reinhardtii. An immunological study based on the use of an antibody specific for the $\beta$-tubulin subunit. J. Biol. Chem. 252: 383-391.

Pryde, G., and J. H. Phillips (1986) Fractionation of membrane proteins by temperature-induced phase separation in Triton X-114. Biochem. J. 233: 525-533.

Routtenberg, A., D. Lovinger, and O. Steward (1985) Selective increase in the phosphorylation of a $47 \mathrm{kDa}$ protein (F1) directly related to long-term potentiation. Behav. Neural Biol. 43: 3-11.

Schwartz, J. H. (1979) Axonal transport: Components, mechanisms and specificity. Annu. Rev. Neurosci. 2: 467-504.

Simkowitz, P., and K. H. Pfenninger (1983) Rapidly transported proteins of nerve growth cones and synaptic endings are markedly different. Soc. Neurosci. Abstr. 9: 1178

Skene, J. H. P., and M. Willard (1981a) Changes in axonally transported proteins during axonal regeneration in toad retinal ganglion cells. J. Cell Biol. 89: 86-95

Skene, J. H. P., and M. Willard (1981b) Axonally transported proteins associated with axon growth in rabbit central and peripheral nervous system. J. Cell Biol. 89: 96-103.

Skene, J. H. P., R. D. Jacobson, G. J. Snipes, C. B. McGuire, J. J. Norden, and J. A. Freeman (1986) A protein induced during nerve growth (GAP-43) is a major component of growth-cone membranes. Science 233: 783-786.

Snipes, G. J., S. Y. Chan, C. B. McGuirc, B. R. Costcllo, J. J. Norden, J. A. Freeman, and A. Routtenberg (1987) Evidence for the coidentification of GAP-43, a growth-associated protein, and F1, a plasticityassociated protein. J. Neurosci. 7: 4066-4075.

Soifer, D., and H. Czosnek (1980) Association of newly synthesized tubulin with brain microsomal membranes. J. Neurochem. 35: 1128 1136.

Theiler, R. F., and W. O. McClure (1978) Rapid axoplasmic transport of proteins in regenerating sensory nerve fibers. J. Neurochem. 31 . 433-447.

Towbin, H., T. Staehelin, and J. Gordon (1979) Electrophoretic transfer of proteins from polyacrylamide gels to nitrocellulose sheets: Procedure and some applications. Proc. Natl. Acad. Sci. USA 76: 43504354.

Wallis, I., L. Ellis, K. Suh, and K. H. Pfenninger (1985) Immunolocalization of a neuronal growth-dependent membrane glycoprotein. J. Cell Biol. 101: 1990-1998.

Weber, K., and M. Osborn (1969) The reliability of molecular weight determinations by dodecyl-sulfate-polyacrylamide gel electrophoresis. J. Biol. Chem. 244: 4406-4412.

Weiss, D. G., V. Krygier-Brevart, E. Mehl, and G. W. Kreutzberg (1979) Subcellular distribution of proteins delivered to the synapse by rapid axoplasmic transport. Biol. Cell. 34: 59-64.

Willard, M. B., K. Meiri, and M. Glicksman (1985) Changes of state during neuronal development: Regulation of axon elongation. In The Molecular Bases of Neuronal Development, G. M. Fidelman, W. E. Gall, and W. M. Cowan, eds., pp. 341-361, Wiley, New York.

Yuen, K. C. L., T. K. Johnson, R. E. Denell, and R. A. Consigli (1983) A silver staining technique for detecting minute quantities of proteins on nitrocellulose paper: Retention of antigenicity of stained proteins. Anal. Biochem. 1216: 398-402. 